\title{
PRIVATE EQUITY FIRMS AS GATEKEEPERS
}

\author{
ELISABETH DE FONTENAY ${ }^{*}$
}

\begin{abstract}
Notwithstanding the considerable attention private equity receives, there continues to be substantial confusion about what private equity does and whether this creates value. Calls for more aggressive regulation of the industry reflect a skeptical view of private equity as-at best - a zero-sum game, in which profits are generated only at the expense of other constituencies. The standard defense of private equity points to its corporate governance advantages as a source of value. This Article identifies an overlooked and increasingly important way in which private equity creates value: private equity firms act as gatekeepers in the debt markets. As repeat players, private equity firms use their reputations with creditors to mitigate the problems of borrower adverse selection and moral hazard in the companies that they manage, thereby reducing creditors' costs of lending to these companies. Private equity-owned companies are thus able to borrow money on more favorable terms than standalone companies, all else being equal. By acting as gatekeepers, private equity firms render the debt markets more efficient and provide their portfolio companies with an increasingly valuable borrowing advantage. Ironically, then, debt may well be private equity's greatest asset.
\end{abstract}

\footnotetext{
* Associate Professor, Duke University School of Law. For comments, discussions, or suggestions, I thank John Coates, Michael Coenen, James Coleman, Jim Cox, Seth Davis, Catherine de Fontenay, Jesse Fried, Jake Gersen, Victoria Ivashina, Howell Jackson, Ed Kleinbard, Jeff Lipshaw, Reinier Kraakman, Josh Lerner, Stephen Shay, Matthew Stephenson, Seth Stoughton, Susannah Barton Tobin, and workshop participants at Harvard Law School. Kyle Watson provided helpful research assistance. All errors are mine.
} 


\section{Table of Contents}

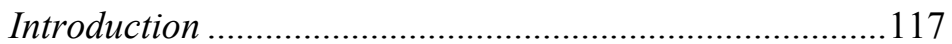

I. The Private Equity Puzzle ..................................................121

A. Background: Private Equity LBO Transactions..........121

B. Searching for Value in Private Equity..........................124 124

II. Private Equity Gatekeeping: Thesis and Framework ........134

A Claims and Assumptions ...........................................134

B. Gatekeeping in the Financial Markets-

A Framework ............................................................ 136

C. Broadening the Gatekeeper Concept............................ 138

III. Private Equity Gatekeeping: Application ...........................139

A. The Agency Costs of Debt .........................................140

B. Private Equity Firms' Incentive to Mitigate Agency Costs ............................................................ 148

C. Private Equity Firms' Ability to Mitigate Agency Costs ............................................................ 158

IV. Measuring Private Equity's Gatekeeping Performance ....161

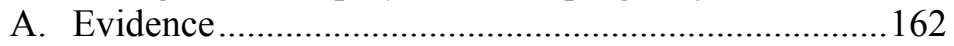

B. Additional Hypotheses for Private Equity Borrowing Advantage ................................................ 166

V. $\quad$ Grading Private Equity's Gatekeeping Performance .........169

A. Limitations on Private Equity's Gatekeeping ............. 169

B. A Word on Credit Rating Agencies ............................ 176

C. Regulatory Implications ............................................. 180

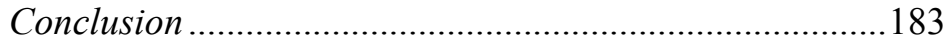

Appendix A: Repeated-Game Model of Private Equity

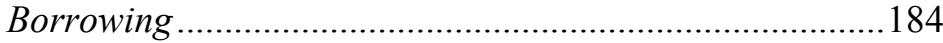




\section{Introduction}

Private equity - the business of buying and selling companies - is seemingly ubiquitous. Whether prompted by the fallout from the financial crisis or Mitt Romney's 2012 presidential campaign, private equity has caught the public's attention, resulting in a barrage of conflicting claims as to private equity's social worth, or lack thereof. ${ }^{1}$

Public interest in private equity is unsurprising. Since its beginnings in the 1980s, private equity activity has grown dramatically, albeit in a highly cyclical fashion. ${ }^{2}$ Its most recent peak of activity coincided with the unprecedented merger wave of 2004 to 2007 and came to an abrupt halt when the subprime-mortgage collapse caused the debt markets to seize up. ${ }^{3}$ The frenetic pace of activity during that period generated untold wealth for the largest private equity firms (KKR, Carlyle, Apollo, and the like), which in turn led to widespread calls to regulate and tax the industry more aggressively, both in the U.S. and abroad. ${ }^{4}$

${ }^{1}$ For an overview of the different views on private equity, see Julie Creswell, Profits for Buyout Firms as Company Debt Soared, N.Y. TIMES, Oct. 5, 2009, at A1; Steven M. Davidoff, With Private Equity Under Attack, Academia Tries to Quantify Its Value, N.Y. TIMES, Jan. 25, 2012, at B4; James Surowiecki, Private Inequity, THE New Yorker, Jan. 30, 2012, at 21; Jia Lynn Yang, Romney's Bain Capital Tenure Shows Mixed Bankruptcy Record, WASH. POST, Dec. 15, 2011, at A8; The Bain Capital Bonfire, WALL ST. J. (Jan. 13, 2012), http://online.wsj.com/article/ SB10001424052970204879004577108500491449164.html.

${ }^{2}$ At its most recent peak of activity in 2006, private equity represented over $20 \%$ of all mergers and acquisitions in the United States. Marc Martos-Vila, Matthew Rhodes-Kropf \& Jarrad Harford, Financial vs. Strategic Buyers 2 (Nat'l Bureau of Econ. Research, Working Paper No. 19378, 2013), available at http://www.lse.ac.uk/fmg/events/capitalMarket/pdf/CMW55 Vila_M.pdf.

${ }^{3}$ See generally Steven M. Davidoff, The Failure of Private Equity, $82 \mathrm{~S}$. CAL. L. ReV. 481 (Mar. 2009); EILEen ApPelbaum \& Rosemary Batt, CTR. FOR ECON. \& POlicy ReSEARCh, A PRIMER ON PRIVATE EQUity AT WORK 11 (Feb. 2012), available at http://www.cepr.net/documents/ publications/private-equity-2012-02.pdf (explaining that "[d]eal activity slowed substantially beginning in the second half of 2007, and by 2009 was below its level [in] 2003").

${ }^{4}$ Raising Taxes on Private Equity, N.Y. TIMES, June 25, 2007, at A18. 
Negative public sentiment towards private equity stems from the sense that its success comes solely at others' expense. ${ }^{5}$ On this view, private equity is a particularly ingenious type of wealth transfer, in which private equity firms "privatize[] the gains and socialize[] the losses." If the characterization of private equity as a mere shell game is warranted, the demands to curtail it should be heeded. But if instead private equity creates social value, the regulatory calculus is considerably more complex.

The defense of private equity hews to a now-familiar story. ${ }^{7}$ Private equity creates value, the argument goes, by providing better corporate governance, particularly as compared to public-company governance. $^{8}$ With public companies, ownership (by dispersed shareholders) is divided from control (by management), giving rise to the familiar agency costs of management: managers have incentives to shirk, to use company assets for private benefits, and so forth, while public shareholders face a collective action problem preventing them from adequately supervising and incentivizing management. ${ }^{9}$ With private equity, however, ownership and control are reunited in the companies that private equity firms acquire (their "portfolio companies"). ${ }^{10}$ As the sole or controlling shareholder, ${ }^{11}$

${ }^{5}$ In this depiction of private equity, the losers have at various points been identified as taxpayers, workers, creditors, selling shareholders of target companies, and even the investors in private equity funds. See discussion infra Part I.B.1.

6 Anthony Luzzatto Gardner, Romney's Bain Yielded Private Gains, Socialized Losses, BloOMBERG VIEW (July 15, 2012, 6:30 PM), http://www.bloomberg.com/news/2012-07-15/romney-s-bain-yieldedprivate-gains-socialized-losses.html.

${ }^{7}$ See discussion infra Part I.B.2.

${ }^{8}$ Steven N. Kaplan \& Per Strömberg, Leveraged Buyouts and Private Equity, 23 J. ECON. PERSP. 121, 121-22 (2009).

${ }^{9}$ Scott J. Davis, Would Changes in the Rules for Director Selection and Liability Help Public Companies Gain Some of Private Equity's Advantages?, 76 U. CHI. L. REV. 83, 85 (2009). For the original description of this feature of modern corporations, see ADOLPH A. BERLE, JR. \& Gardiner C. Means, The Modern Corporation ANd Private Property 277-79 (1933).

${ }^{10}$ Kaplan \& Strömberg, supra note 8, at 123.

11 As discussed infra in Part I, private equity portfolio companies are actually owned by the private equity fund (rather than the private equity firm). Francesco Baldi, Private Equity Targets: Strategies For GROWTH, MARKET BARRIERS AND POLICY IMPLICATIONS 9 (2013). Because a private equity fund delegates all managerial authority for its portfolio 
private equity firms have both the ability and the incentives to ensure that their portfolio companies' management acts in the private equity firms' best interests. On this theory, then, private equity firms create value by reducing the agency costs of management. Our understanding of private equity has stalled in this debate over wealth transfers versus corporate governance benefits for quite some time.

This Article tells a different story about private equity: private equity firms create value by acting as gatekeepers in the debt markets. ${ }^{12}$ They do so by reducing the agency costs of debt in their portfolio companies. As repeat players in the debt markets, private equity firms establish reputations with creditors that are tied to the credit performance of their portfolio companies. In turn, they use their reputations in the debt markets both to certify the creditworthiness of their portfolio companies ex ante and to bond against misconduct or poor performance by their portfolio companies ex post. Private equity firms thereby mitigate the problems of borrower adverse selection and moral hazard that plague creditors and increase lending costs above the efficient equilibrium.

The most obvious benefit from this gatekeeping role is that, all else being equal, it should allow private equity-owned companies to borrow money on better terms than standalone companies, whether public or private. ${ }^{13}$ Thus, private equity-owned companies have not only a governance advantage, but also a borrowing advantage over other companies. Private equity firms reduce companies' cost of debt capital and creditors' lending costs, rendering the debt markets more efficient.

Crucially, private equity's gatekeeping role should be increasingly valuable in light of recent sweeping changes in the corporate loan markets. ${ }^{14}$ Lenders' traditional methods of controlling borrower adverse selection and moral hazard-screening,

companies to the private equity firm, references throughout this Article to a private equity firm as the "sole" or "controlling" shareholder of a portfolio company are simply intended as shorthand. The more accurate description of the private equity ownership structure is used each time it leads to relevant distinctions, as in Part V.C, infra.

${ }^{12}$ See discussion infra Parts II-III, Appendix A.

13 Victoria Ivashina \& Anna Kovner, The Private Equity Advantage: Leveraged Buyout Firms and Relationship Banking, 24 REV. FIN. STUD. 2462, 2466 (2011).

${ }^{14}$ See discussion infra Part III.A.4 (summarizing current trends in debt markets). 
monitoring, and covenants - are in sharp decline. ${ }^{15}$ Less than three decades ago, relationship banking was the dominant corporate lending model, giving banks the incentive and ability to monitor their borrowers closely. ${ }^{16}$ Today, however, corporate loans are typically funded by large numbers of both bank and non-bank creditors and may be traded or securitized to reach still more investors. ${ }^{17}$ Through this process, the information and control gap between borrowing companies and their ultimate creditors has increased significantly, while creditors' incentives to monitor their borrowers have declined. ${ }^{18}$ Today's creditors are thus dependent on others to signal borrowers' creditworthiness. Private equity firms fulfill precisely this role. Accordingly, gatekeeping by private equity firms should be an increasingly valuable - though imperfect - substitute for traditional bank monitoring. After a post-financial crisis lull, private equity transactions are again picking up steam. ${ }^{19}$ It should come as no surprise that lenders are clamoring to fund them.

The conception of private equity firms as gatekeepers advances the literature on private equity and the literature on gatekeeping, both of which are limited by their unerring focus on the problem of public company governance. As to the first, this Article reaches the novel conclusion that gatekeeping, not just governance, accounts for much of private equity's value. Private equity is less about optimizing companies' operations and governance than about brokering cheap financing. The corporate governance defense of private equity is thus not only incomplete, but likely overstated. We

${ }^{15}$ Charles K. Whitehead, The Evolution of Debt: Covenants, the Credit Market, and Corporate Governance, 34 J. CORP. L. 641, 643-44 (2009) (asserting that monitoring and covenants are no longer the most costefficient ways to manage credit risk).

${ }^{16}$ Scott Page \& Payson Swaffield, An Introduction to the Loan Asset Class, in THE HANDBOOK OF LOAN SyNDiCATION AND TRAdiNG 22-23 (Allison Taylor \& Alicia Sansone eds., 2007).

${ }^{17}$ Whitehead, supra note 15 , at 643.

${ }^{18} I d$. at 645.

${ }^{19}$ Private equity went quiet for a stretch after its 2004 to 2007 heyday, first due to lack of capital and then due to overvalued targets and a dismal initial public offering ("IPO") market, a key exit for private equity investments. Kaplan \& Strömberg, supra note 8, at 127. There have been signs of an uptick in private equity activity, however, exemplified by the announcement of the $\$ 24$ billion leveraged buyout of Dell led by the private equity group Silver Lake Partners. Matt Wirz, A Reboot for Buyouts? Depends on Dell Deal, Wall St. J., Jan. 18, 2013, at C1. 
should think of private equity firms as lending to companies not only their operational expertise, but also (and perhaps more importantly) their financial reputations. As to the second, this Article demonstrates that there is a broader array of gatekeepers and gatekeeping strategies than scholars typically suppose. The foundational example of a gatekeeper is that of an independent professional organization such as an audit firm that certifies companies for the benefit of investors. Yet the same frameworks that have proven useful in identifying when such gatekeepers will be successful apply equally well to "insider" gatekeepers such as private equity firms and to their more expansive form of gatekeeping, which includes not only the traditional certification function, but also monitoring through direct control and selecting more credit-worthy companies ex ante.

This Article proceeds as follows. Part I provides a background on the mechanics of private equity acquisitions and financings, and summarizes the literature on private equity's social worth. Part II sets forth the claim that private equity firms act as gatekeepers in the debt markets, and introduces a simple framework for identifying financial-market gatekeepers. Applying this framework to today's debt markets, Part III demonstrates conceptually how and why private equity firms act as gatekeepers. Part IV assesses private equity firms' performance as gatekeepers by interpreting available evidence and distinguishing other hypotheses for the private equity borrowing advantage. Part $\mathrm{V}$ identifies potential limitations on the gatekeeping role of private equity firms and compares them to the more established debt-market gatekeepers, the credit rating agencies. It concludes with a brief discussion of the current regulatory implications of private equity firms' gatekeeping function. Finally, Appendix A provides a formal proof of the gatekeeper thesis, modeling the interactions between private equity firms and lenders as a repeated-game involving agency costs.

\section{The Private Equity Puzzle}

\section{A. Background: Private Equity LBO Transactions}

Although the term "private equity" may be used to refer to a broad range of private investing, for purposes of this Article, private equity is defined as the business of buying and selling whole 
companies, using (in part) borrowed money. ${ }^{20}$ A "private equity firm" is a group of investment professionals that raises money from investors ${ }^{21}$ and pools it in one or more investment vehicles ("private equity funds") for the purpose of engaging in private equity. ${ }^{22}$ When a private equity fund acquires a company - a transaction referred to as a "leveraged buyout" or "LBO"-only a portion of the acquisition price, typically $10-40 \%$, comes from its own pooled funds. ${ }^{23}$ The remaining $60-90 \%$ of the purchase price is borrowed from third parties. ${ }^{24}$ The borrower in an LBO is neither the private equity firm nor the private equity fund, but rather the target company itself. ${ }^{25}$ The key characteristic of an LBO is that the target company is made to borrow against its own assets to buy out existing shareholders. ${ }^{26}$ Thus, while the private equity firm negotiates the target company's debt terms with creditors, the creditors have recourse only to the assets of the target, and not those of the private equity firm, the private equity fund, or any other portfolio company of the private equity firm. ${ }^{27}$ Upon completion of the acquisition (as depicted in Figure 1 below), the private equity fund is the controlling shareholder of a highly leveraged company, that is, one with a high ratio of debt to equity. ${ }^{28}$

${ }^{20}$ In other words, this Article focuses on a particular type of private equity transaction, the leveraged buyout ("LBO"). LBO funds invest in mature companies (in contrast to venture capital funds, which invest in start-ups) by acquiring a controlling ownership interest in the company (in contrast to hedge funds, which most typically make minority investments in publiclytraded corporations). Kaplan \& Strömberg, supra note 8, at 121.

${ }^{21}$ Private equity firms raise these large pools of funds from institutional investors (such as pension funds, university endowments, foreign governments, etc.) and high net-worth individuals, who delegate to the firms all authority to acquire and dispose of companies with the funds. Id. at 123.

${ }^{22} I d$.

${ }^{23} I d$. at 125.

${ }^{24} \mathrm{Id}$. at 124 .

${ }^{25}$ APPELBAUM \& BATT, supra note 3, at 14.

${ }^{26} 19$ AM. JUR. 2d Corporations § 2181 (2013) (“A 'leveraged buyout' or LBO is a method of acquiring a company by which the acquirer leverages (or borrows against) the assets of the target company to finance the purchase of the target company's shares from the selling shareholders.").

${ }^{27}$ APPELBAUM \& BATT, supra note 3, at 14.

${ }^{28}$ An operating company's leverage may be measured by either the ratio of debt to equity or the ratio of debt to the accounting measure of earnings before interest, taxes, depreciation, and amortization ("EBITDA"). SIDNEY 


\section{Figure 1. Private Equity Acquisition Structure (Simplified) ${ }^{29}$}

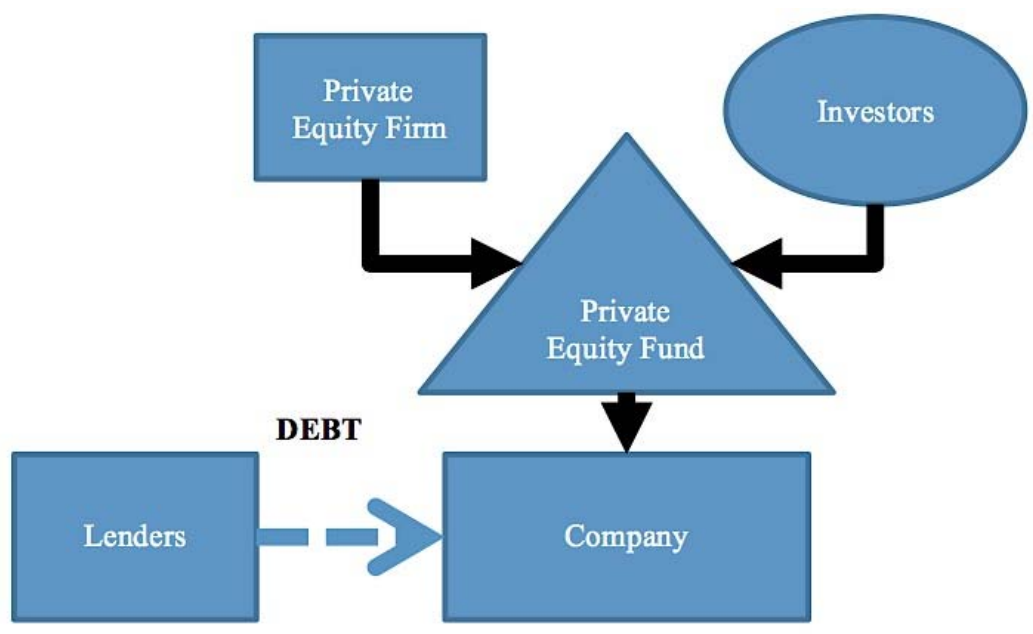

A private equity firm manages one or more private equity funds at once, and each such fund typically holds several companies at once. ${ }^{30}$ Each portfolio company issues its own debt, which may consist of senior loans ("bank debt"), high-yield bonds, mezzanine debt, or some combination thereof. ${ }^{31}$ While the private equity fund is the actual owner of the portfolio companies, the investors in a private equity fund have a purely passive role. ${ }^{32}$ The private equity firm is solely responsible for identifying acquisition targets, ${ }^{33}$ providing

S. Goldstein, 1 Advising SMall Businesses $\S 12: 31$ (2013); Richard Wight, Warren Cooke \& Richard Gray, Understanding the Credit Agreement, in THE HANDBOOK OF LOAN SyNDICATIONS AND TRADING 209, 298 (Allison Taylor \& Alicia Sansone eds., 2007). The distinction between the two is irrelevant for purposes of this Article.

${ }^{29}$ Solid arrows in the figure indicate ownership.

${ }^{30}$ Brian Cheffins \& John Armour, The Eclipse of Private Equity, 33 DEL. J. CORP. L. 1, 9 (2008).

${ }^{31}$ Kaplan \& Strömberg, supra note 8, at 124-25.

${ }^{32}$ In the United States, the private equity fund is most commonly organized as a limited partnership, of which the private equity firm is the general partner and the passive investors are the limited partners. Id. at 123.

${ }^{33}$ Private equity funds may acquire both public companies (in a "going private" transaction) and companies that are already privately held. $I d$. at 127-28. 
management services to any acquired companies (including by negotiating their financings), and, after a few years, selling them off again. ${ }^{34}$

Figure 2. Full Private Equity Ownership Structure (Simplified)

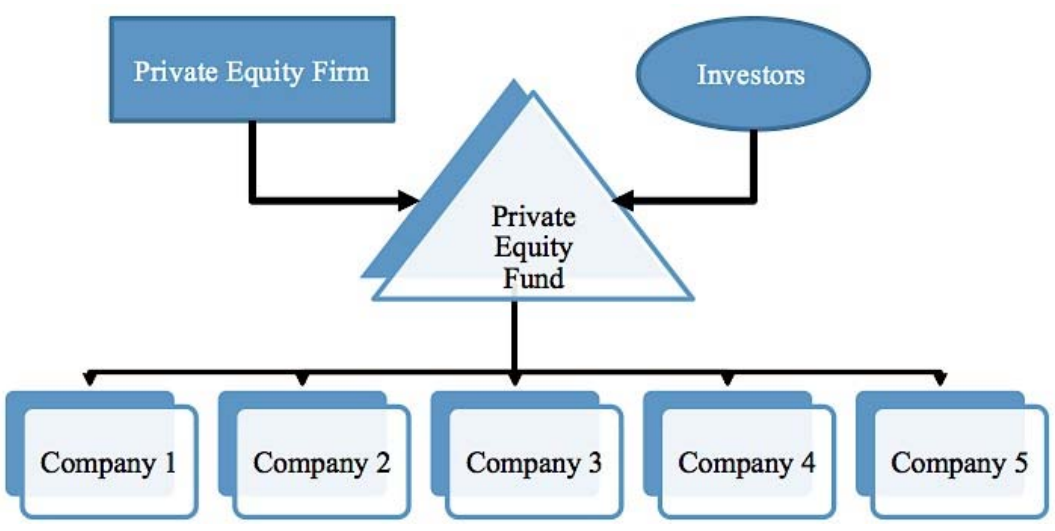

\section{B. Searching for Value in Private Equity}

As private equity has expanded both in size and scope since its beginnings in the $1980 \mathrm{~s}$, the debate as to its merits has intensified. ${ }^{35}$ Immediately prior to the 2007 to 2008 financial crisis, the characterization of private equity firms as "Barbarians at the Gate" ${ }^{36}$ seemed to be a historical artifact. However, with the onset of the financial crisis, the continuing economic difficulties in the United States, and Mitt Romney's presidential campaign, private equity

${ }^{34}$ See APPELBAUM \& BATT, supra note 3, at 13 ("The general partner makes decisions about which properties or companies to buy, how they should be managed, and when they should be sold."). After owning a company for the desired period (say, three to eight years), a private equity fund will generally exit the investment in one of three ways by: (1) taking the company public through an IPO, (2) selling it to another company seeking to make a strategic acquisition (e.g., a large operating company looking for synergies), or (3) selling it to another LBO fund (a "secondary LBO"). Kaplan \& Strömberg, supra note 8, at 129.

${ }^{35}$ For a brief, non-technical review of the studies and theories on the costs and benefits of private equity, see Davidoff, supra note 1, at B4.

${ }^{36}$ Bryan Burrough \& JOHn Helyar, Barbarians at the Gate: The FALL OF RJR NABISCO (1990). 
once again became a focus of (largely negative) public scrutiny. ${ }^{37}$ This sub-part summarizes the extant literature and views on whether private equity creates value. ${ }^{38}$

\section{Private Equity Skeptics}

Skepticism about private equity boils down to the view that private equity is nothing more than a transfer of wealth from less sophisticated or less organized parties (such as selling shareholders, dispersed creditors, workers, and taxpayers) to the pockets of private equity professionals and, possibly, their investors. ${ }^{39}$

One form of such skepticism views private equity as pure financial trickery. ${ }^{40}$ This view expresses surprise bordering on disbelief that private equity firms appear to generate above-market returns from their portfolio companies. ${ }^{41}$ The reason is simply that, to casual observers, private equity firms do not appear to do much of anything. They purchase companies, attend board meetings, and then sell to the highest bidder after a few years. ${ }^{42}$ If capital markets are efficient, this process should not lead to above-market returns for private equity firms or their investors. ${ }^{43}$

Such skeptics are in fact correct that private equity firms rarely implement drastic changes in their portfolio companies. While

\footnotetext{
${ }^{37}$ See sources cited supra note 1.

38 The literature and press on private equity frequently conflate four overlapping, yet distinct questions: (1) whether private equity generates profits for private equity firms, (2) whether private equity generates profits for investors in private equity funds, (3) whether private equity increases social welfare overall, and (4) whether private equity creates any social value (which may or may not result in a net increase in social welfare, depending on the social costs that private equity imposes). This sub-part is primarily concerned with the fourth question.

${ }^{39}$ Robert J. Samuelson, The Private Equity Boom, WASH. Post (Mar. 15, 2007), http://www.washingtonpost.com/wp-dyn/content/article/2007/03/14/ ar2007031402177.html.

${ }^{40}$ E.g., Michael Gordon, Private Equity Boom Was a Clumsy Trick, Fin. TIMES, Apr. 1, 2009, at 9.

${ }^{41} I d$.

${ }^{42}$ Cheffins \& Armour, supra note 30, at 11.

${ }^{43}$ Kaplan \& Strömberg, supra note 8, at 122 (suggesting that private equity firms generate profits-despite not increasing the value of portfolio companies - by taking advantage of favorable market timing and market mispricing).
} 
they sit on their companies' boards and provide them with advisory services (usually related only to major corporate events such as financings and acquisitions), they do not take over day-to-day management duties of their companies. ${ }^{44}$ Nor do they consistently replace management when they acquire a company-in fact, they proudly advertise their goal of teaming up with existing management when they make acquisitions and are viewed as friendlier to management than other acquirers. ${ }^{45}$ To such a critic, then, private equity necessarily involves a financial sleight-of-hand, either in the buying or selling of companies (e.g., private equity firms are consistently able to buy low and sell high only by preying on the ignorance of public shareholders) or in the calculation or publication of its returns. ${ }^{46}$

Under the second form of skepticism, the harms imposed by private equity extend well beyond the financial realm. ${ }^{47}$ Here, private equity is criticized for reducing social welfare by: (1) bankrupting U.S. companies, ${ }^{48}$ (2) harming American workers, ${ }^{49}$ (3) pocketing unjustified tax subsidies, ${ }^{50}$ or all of the above.

First, private equity firms are said to cause companies to take on too much debt, and to use that debt solely for the benefit of the

${ }^{44}$ Cheffins \& Armour, supra note 30, at 13 (explaining that while "general partners can use their power at the board level to execute a swift executive turnover," they instead generally "opt for an advisory role").

${ }^{45}$ See Michael Klausner, Institutional Shareholders, Private Equity, and Antitakeover Protection at the IPO Stage, 152 U. PA. L. REV. 755, 770-75 (2003) (describing the interest of private equity funds in "maintaining a reputation for treating successful managers well").

${ }^{46}$ Even serious commentators argue that private equity investors may be getting lower returns than private equity firms claim. See Dan McCrum, Private Equity Fees Called into Question, Fin. TIMES, Jan. 23, 2012 at 1. However, this debate touches more on the division of profits between the private equity managers (the investment professionals) and their investors than on whether private equity generates value as a whole. $I d$.

${ }^{47}$ Creswell, supra note 1 , at A1.

${ }^{48} I d$. (blaming private equity firms for sending many U.S. companies into bankruptcy).

${ }^{49}$ Steven J. Davis et al., Private Equity and Employment 32 (Nat'l Bureau of Econ. Research, Working Paper No. 17399, 2011), available at http://faculty.chicagobooth.edu/steven.davis/pdf/privateequityandemployme nt.pdf (finding that "pre-existing employment positions are at greater risk of loss in the wake of private equity buyouts").

${ }^{50}$ Surowiecki, supra note 1 , at 21. 
private equity firm - whether explicitly (by issuing themselves a large dividend) ${ }^{51}$ or implicitly (by using the debt to outbid other potential acquirers of a company) ${ }^{52}$-rather than for the benefit of the companies. By stripping cash out of U.S. companies, perhaps private equity firms leave companies too susceptible to bankruptcy. ${ }^{53}$ Even if these companies manage to avoid bankruptcy, the argument goes, they will be left with too little cash to invest in long-term, value-creating projects, with negative long-term consequences for the U.S. economy. ${ }^{54}$ On this view, private equity firms keep all of the upside from their portfolio companies' performance, while the downside is borne by creditors and by the general public.

${ }^{51}$ David Callahan, Bad Debts, Big Profits: How Private Equity Firms Turn Red Ink into Gold, HufFInGTON POST (May 23, 2013, 1:45 PM), http://www.huffingtonpost.com/david-callahan/bad-debts-big-profits-

how_b_1539328.html (explaining that private equity firms use debt to "create a pile of cash, some of which they can direct their own way in the form of management fees and dividends").

${ }^{52}$ Robert P. Bartlett III, Taking Finance Seriously: How Debt Financing Distorts Bidding Outcomes in Corporate Takeovers, 76 FORDHAM L. REV. 1975, 1980 (2008) (arguing that debt financing provides private equity firms with an advantage over other potential acquirers of a target company).

${ }_{53}^{53}$ E.g., Surowiecki, supra note 1 , at 21.

${ }^{54}$ Several recent empirical projects offer serious challenges to these claims, however. Private equity-owned portfolio companies are found to default on their loans at the same or lower rates as comparable non-sponsored companies. Edie Hotchkiss, David C. Smith \& Per Strömberg, Private Equity and the Resolution of Financial Distress 23-24 (Eur. Corp. Governance Inst., Finance Working Paper No. 331/2012, 2011); see also Kaplan \& Strömberg, supra note 8, at 129 (finding a lower default rate for their sample of private equity-owned companies than for all U.S. corporate bond issuers from 1980 to 2002). Further, the costs of financial distress appear to be lower for private equity-owned companies, as they achieve voluntary restructuring more often and, if that fails, spend less time in bankruptcy. Hotchkiss et al., supra, at 23-24 (asserting that private equity firms actively facilitate the restructuring of firms, and shorten the bankruptcy process by pre-negotiating bankruptcy terms and aiding in the screening process). Finally, several papers have produced evidence that private equity portfolio companies innovate more, engage in more research and development, and generally invest more (more efficiently) than their public company counterparts. E.g., Josh Lerner, Morten Sorensen \& Per Strömberg, Private Equity and Long-Run Investment: The Case of Innovation, 66 J. FIN. 445, 446, 474 (2011). 
Second, critics complain that the wealth of private equity firms is generated at the expense of workers, who may be laid off en masse following a private equity acquisition (or lose their jobs in a future bankruptcy, as discussed above). ${ }^{55}$ Private equity firms may indeed be slightly more willing to lay off workers than comparable public companies. ${ }^{56}$ However, recent evidence suggests that these layoffs are more than offset by the higher growth rates and subsequent hiring of private equity-owned companies; on a net basis, private equity firms create more jobs than comparable public companies. ${ }^{57}$ Notwithstanding this evidence, it could still be the case that private equity's labor track record involves a net welfare loss, if the unmeasured social costs from firing some workers (social unrest, psychological distress, crime, etc.) are greater than the benefits of creating more jobs overall.

Finally, private equity is criticized for exploiting two key subsidies from U.S. taxpayers: (1) the deductibility of interest payments and (2) the capital gains treatment of carried interest payments. First, because private equity depends on the ability to borrow substantial amounts of debt, it undeniably benefits from the fact that interest payments on debt are generally tax-deductible for corporations, ${ }^{58}$ while payments on stock - such as dividends and redemptions - are not. ${ }^{59}$ The tax advantage of debt implies that private equity firms may increase the value of their portfolio companies simply by making greater use of leverage than public companies tend to. ${ }^{60}$ Proponents of this view argue that private equity's success is entirely tax-driven, and what Congress gives, Congress can (and perhaps should) take away. ${ }^{61}$ If the private equity

55 E.g., Matthew T. Bodie, Mother Jones Meets Gordon Gekko: The Complicated Relationship Between Labor and Private Equity, 79 U. CoLO. L. REV. 1317, 1329-31 (2008).

${ }^{56}$ Davis et al., supra note 49, at 5-7 (finding layoff rates at acquired companies typically increase at rates slightly higher than "control" companies (i.e., companies in similar financial situations that have not undergone private equity takeovers)).

${ }^{57} \mathrm{Id}$. at 4 .

${ }_{55}^{58} 26$ U.S.C. $\$ 163$ (a) (2006).

${ }^{59}$ BORIS I. BitTKER \& JAMES S. EUSTICE, FEDERAL INCOME TAXATION OF CORPORATIONS AND SHAREHOLDERS $\S 4.01$ (2013).

${ }^{60}$ Kaplan \& Strömberg, supra note 8, at 131.

${ }^{61}$ Surowiecki, supra note 1, at 21 (arguing that Congress should alter the U.S. tax code to close the "loopholes" through which private equity firms make money). 
value-add is simply causing companies to adopt a tax-efficient level of debt, it is not necessarily a socially optimal one.

Second, private equity professionals pay tax on much of their income at lower rates than they would as salaried workers. ${ }^{62} \mathrm{~A}$ significant portion of the compensation of private equity managers consists of the gains from selling their portfolio companies, referred to as the "carried interest." ${ }^{\text {"63 }}$ Currently, carried interest income is treated as capital gains under the U.S. tax laws and is therefore generally subject to tax at a reduced rate. ${ }^{64}$ Critics complain that the carried interest is the product of the private equity managers' labor, not mere passive gain, and should therefore be treated as ordinary income, which would be taxable at higher rates. ${ }^{65}$ On this view, the capital gains treatment for carried interest income is an unjustified subsidy to the private equity industry, allowing it to draw the best and brightest young professionals away from the fields in which they would otherwise have exercised their talents. ${ }^{66}$

\section{Proponents of Private Equity}

Those who champion private equity adopt two strategies in responding to critics. The first is to show that the claimed harms

${ }^{62}$ Thomas J. Brennan \& Karl S. Okamoto, Measuring the Tax Subsidy in Private Equity and Hedge Fund Compensation, 60 Hastings L.J. 27, 3942 (2008); David A. Weisbach, The Taxation of Carried Interests in Private Equity, 94 VA. L. REV. 715, 729-30 (2008).

${ }^{63}$ Kaplan \& Strömberg, supra note 8, at 124 (defining "carried interest" as the share of profits of the fund a general partner earns, which frequently equals almost $20 \%$ ).

${ }^{64}$ StafF OF THE JOINT COMM. ON TAX'N, 110TH CONG., PRESENT LAW AND Analysis Relating to TAX TREATMENT OF PARTNERShip CARried InTERests AND ReLATED IsSUES, PART I, JCX-62-07, 3. This was the explanation given by Mitt Romney for why his effective income tax rate is so low. John D. McKinnon \& Sara Murray, Romney Offers New Tax Details, WaLl St. J., Sept. 22, 2012, at A1.

${ }^{65}$ E.g., Victor Fleischer, Two and Twenty: Taxing Partnership Profits in Private Equity Funds, 83 N.Y.U. L. REV. 1, 5 (2008).

${ }^{66}$ For proposals to tax all or a portion of private equity's carried interest income as ordinary income, rather than as capital gains, see American Jobs Act of 2011, H.R. 12, 112th Cong. § 412 (2011); American Jobs and Closing Tax Loopholes Act of 2010, H.R. 4213, 111th Cong. Sess. § 412 (2010); H.R. 2834, 110th Cong. (2007). 
imposed by private equity are either illusory or exaggerated. ${ }^{67}$ The second is to identify sources of value from private equity, which might more than offset its costs. This section summarizes arguments employing the latter strategy.

If private equity firms rarely make major operational changes to their portfolio companies, how can they possibly add value? The literature suggests that private equity firms make certain subtle changes that, while modest, have a measurable impact on company performance. ${ }^{68}$ And the use of leverage magnifies the return to shareholders from any such changes.

First and foremost, private equity provides an effective form of corporate governance for its portfolio companies, particularly as compared to the public company model. ${ }^{69}$ Private equity minimizes the severe agency costs that exist with public company management as a result of the separation of ownership (by dispersed shareholders) and control (by hired management). ${ }^{70}$ As compared to dispersed public shareholders, private equity firms may be better at both monitoring and incentivizing management. ${ }^{71}$ Private equity firms monitor management both directly and indirectly. First, private equity firms appear to be more closely involved in management oversight than the independent directors of public companies: their

\footnotetext{
${ }^{67}$ For examples of this strategy, see supra note 54.

${ }^{68}$ Kaplan \& Strömberg, supra note 8, at 122-23; see generally Robert S. Harris, Tim Jenkinson \& Steven N. Kaplan, Private Equity Performance: What Do We Know? (Nat'1 Bureau of Econ. Research, Working Paper No. 17874, 2012), available at http://www.nber.org/papers/w17874 (indicating that, empirically, private equity-owned companies outperform public companies).

${ }^{69}$ Larry E. Ribstein, The Rise of Uncorporation 13-14 (Univ. of Chi. Coll. of Law, Working Paper No. 83, 2007), available at http://law.bepress. $\mathrm{com} / \mathrm{cgi} /$ viewcontent.cgi? article $=1082 \&$ context $=$ uiuclwps.

${ }^{70}$ Id. at 3,22 .

71 Kaplan \& Strömberg, supra note 8, at 131-32. The private equity governance advantage may be increasing as a result of companies' greater use of derivatives in recent years. Ronald W. Masulis \& Randall S. Thomas, Does Private Equity Create Wealth? The Effects of Private Equity and Derivatives on Corporate Governance, 76 U. CHI. L. REV. 219, 245, 251 (2009). Recent work suggests that derivatives render companies more opaque to their boards of directors, thus inhibiting the effective monitoring of management, and that private equity sponsors are more experienced with derivatives than public company boards. $I d$.
} 
portfolio companies have smaller boards that meet more frequently. ${ }^{72}$ Private equity firms also make available to their portfolio companies financial and industry/operational expertise - they specialize in the former, and often hire consultants or executives for the latter. ${ }^{73}$ Second, private equity firms are skilled at identifying underperforming management and, when necessary, replacing them. ${ }^{74}$ Yet the most effective form of monitoring by private equity firms is an indirect one-namely, the disciplining effect of the very high leverage that they impose on their portfolio companies. ${ }^{75}$ The constant pressure of having to make regular interest and amortization payments on the company's debt is thought to keep management focused on maximizing cash flow and firm value. ${ }^{76}$ Further, it eliminates the inefficiencies that arise from having significant cash on hand, which management may be tempted either to hoard for selfinterested reasons or to spend on bad projects. ${ }^{77}$

In addition, private equity firms incentivize management differently from publicly traded companies: (1) they require managers to invest more of their own money in the company (to have more "skin in the game") ${ }^{78}$ (2) a greater proportion of management's compensation is awarded in the form of equity; ${ }^{79}$ and

${ }^{72}$ Francesca Cornelli \& Ōguzhan Karakas, Private Equity and Corporate Governance: Do LBOs Have More Effective Boards?, in 1 THE Globalization OF ALternative InVESTMENTS WORKING PAPERS Volume 1: The Global ECONOMIC IMPACT OF Private EQUity RePORT 2008 65, 72 (World Econ. Forum 2008), available at http://www3. weforum.org/docs/WEF_IV_PrivateEquity_Report_2008.pdf.

${ }^{73}$ Kaplan \& Strömberg, supra note 8, at 132 . The case for the contribution of financial and industry experts may well be overstated, however, given how leanly staffed private equity firms are. Michael C. Jensen, Eclipse of the Public Corporation, HARV. BUS. REV., Sept.-Oct. 1989, at 70.

${ }^{74}$ See Kaplan \& Strömberg, supra note 8, at 132 (explaining one study's finding that in companies with "poorly performing management . . . onethird of chief executive officers . . . are replaced in the first 100 days while two-thirds are replaced at some point over a four-year period.").

${ }^{75}$ Michael C. Jensen, Agency Costs of Free Cash Flow, Corporate Finance and Takeovers, 76 Am. ECON. ReV. 323, 324 (1986).

${ }^{76} \mathrm{Id}$.

77 Id. at 324; Stewart C. Myers, Still Searching for Optimal Capital Structure, 6 J. APPLIED CORP. FIN. 4, 14 (1993).

${ }_{78}$ Kate Burgess \& Peter Smith, Shareholders Split on C\&W's Private Equity-Style Pay Plan, Fin. TIMES, May 24, 2006, at 23.

${ }^{79}$ Masulis \& Thomas, supra note 71, at 251-52. 
(3) the equity awarded to management is comparatively illiquid (since it cannot be cashed out until an event such as an IPO or other sale of the company occurs), which reduces management's incentives to manipulate short-term financial results and keeps it focused on longer-term results. ${ }^{80}$

Second, private equity leads to a more efficient market for corporate control. ${ }^{81}$ At base, LBOs consist of the buying and selling of corporate control and, by deepening the takeover market, should render it more efficient. ${ }^{82}$ And this is so quite apart from the merits of any particular ownership model. While private equity may well constitute a superior governance model to public shareholding for the reasons discussed above, these benefits are not necessary for private equity to render companies more efficient. The mere threat of being acquired should cause companies (more specifically, management) to perform better. Although private equity is presented as a rival to publicly traded stock, the relationship is more accurately described as symbiotic. Buyout funds depend on the existence of inefficient public companies to make outsized returns. ${ }^{83}$ Therefore, the private equity model not only competes with, but relies on, the public company model. In this way, the LBO market provides a de facto check on the inefficiencies of public ownership. ${ }^{84}$

\footnotetext{
${ }^{80}$ Kaplan \& Strömberg, supra note 8, at 130-31.
}

81 M. Todd Henderson \& Richard A. Epstein, The Going-Private Phenomenon: Causes and Implications, 76 U. CHI. L. REV. 1, 6 (2009) (arguing that ensuring private equity remains "a vibrant component of the market for corporate control which is so essential to the efficient operation of public companies").

82 Michael C. Jensen \& Richard S. Ruback, The Market for Corporate Control: The Scientific Evidence, 11 J. FIN. ECON. 5, 9, 23-24 (1983).

${ }^{83}$ Jensen, supra note 73 , at 65.

${ }^{84}$ In keeping with the thesis of this Article, the same point can be made slightly differently. Private equity consists of a form of arbitrage that should lead to more efficient capital markets. Kaplan \& Strömberg, supra at note 8, at 137-38. One of the skills developed by private equity firms is the ability to recognize and act on "mispricings" between the debt and equity markets. Id. Specifically, buyout funds time the debt markets to borrow cheaply in order to acquire inefficient and undervalued public companies. Id. In that manner, private equity funds effectively capitalize on inefficiencies in the debt markets to correct inefficiencies in the equity markets. Id. As arbitrageurs of the two types of capital markets, private equity funds serve the useful purpose not only of eventually reducing price discrepancies 
Third, in taking public companies private, private equity yields cost savings by avoiding public-company securities law disclosure and compliance requirements (such as Sarbanes-Oxley) ${ }^{85}$ and arguably by shielding management from frivolous shareholder lawsuits. ${ }^{86}$ Of course, this benefit exists only while the company remains private, whereas the benefits of private equity-driven operational changes appear to persist for at least several years after the company goes public again. ${ }^{87}$ Further, these cost savings may well be overstated, as many of the larger private equity portfolio companies voluntarily engage in public financial reporting in any event, for example when they issue public bonds. ${ }^{88}$ More importantly, the net social value of these costs savings is unclear, as it depends on the value to society of mandatory information disclosure.

Weighing the evidence on both sides, the academic literature for the most part concludes - tentatively - that private equity is, on net, a positive phenomenon. ${ }^{89}$ Yet private equity may well be too recent and protean a phenomenon for definitive conclusions to be drawn. The work of measuring the known costs and benefits of private equity has only recently begun in earnest, and, I argue, we have overlooked one such benefit entirely. This Article corrects this oversight in the next Part, by identifying an additional way in which private equity creates value.

between the two markets, but also of directly bringing to the market's attention ineffective management in public companies. Id.

${ }^{85}$ Sarbanes-Oxley Act of 2002, Pub. L. No. 107-204, 116 Stat. 745 (codified in scattered sections of 11, 15, 18, 28, 29 U.S.C.).

${ }^{86}$ Henderson \& Epstein, supra note 81, at 3.

${ }^{87}$ Masulis \& Thomas, supra note 71, at 224 n.25.

${ }^{88}$ Robert P. Bartlett III, Going Private but Staying Public: Reexamining the Effect of Sarbanes-Oxley on Firms' Going-Private Decisions, 76 U. CHI. L. REV. 7, 43 (2009) (finding that "after [Sarbanes-Oxley], private bidders are actually more likely to subject themselves to continuing SEC reporting obligations ... when structuring a large-scale take-private transaction").

${ }^{89}$ E.g., Henderson \& Epstein, supra note 81, at 5 (opining that the current assessment of private equity is "positive and promising but complex and nuanced"); Kaplan \& Strömberg, supra note 8, at 143 (concluding that "[t]he empirical evidence is strong that private equity activity creates economic value on average"). 


\section{Private Equity Gatekeeping: Thesis and Framework}

\section{A. Claims and Assumptions}

In the midst of a global recession, with the scarcity of capital still widely decried, a private equity consortium led by TPG Capital was able to borrow $\$ 1.6$ billion to acquire the apparel retailer J.Crew in one of the biggest leveraged buyouts of 2011, valued at approximately $\$ 3.1$ billion. ${ }^{90}$ J.Crew went from a pre-acquisition capital structure with no material debt to one financed with $60 \%$ debt. ${ }^{91}$ Despite such high leverage, TPG was able to negotiate the debt on highly favorable terms. Although rated speculative grade due to the high leverage, the J.Crew loans had certain borrower-friendly features that were then rarely extended even to borrowers with investment-grade rated loans. ${ }^{92}$ What can account for these favorable debt terms? And is this a good thing?

The primary claim of this Article is that private equity firms create value by acting as gatekeepers in the debt markets. As repeat players in the debt markets, private equity firms have the reputational incentive to minimize the credit risk of their portfolio companies, and they do so by acting as both "certification intermediaries" 93 and what I will refer to as "monitoring intermediaries" between their portfolio companies and creditors.

From this primary claim follows a secondary one: private equity-owned companies have not only a governance advantage, but also a borrowing advantage. ${ }^{94}$ If the gatekeeper hypothesis is correct,

${ }^{90}$ J.Crew Grp., Registration Statement (Form S-4), at 14, (June 22, 2011) [hereinafter J.Crew S-4]; Michael J. de la Merced, J.Crew Shareholders Approve \$3 Billion Deal, N.Y. Times, Mar. 2, 2011, at B5.

${ }^{91}$ J.Crew S-4, supra note 90, at 14.

${ }^{92}$ In particular, the J.Crew term loans were "covenant-lite," meaning that the company was not required to maintain leverage at or below a certain threshold throughout the term of the loan. See id. at F-24. Instead, the company is only subject to a leverage test at the time that it seeks to incur additional debt. Id. at II-6, Exhibit 10.2 (Credit Agreement), available at http://www.sec.gov/Archives/edgar/data/1051251/000119312511062380/de $\mathrm{x} 102$.htm (Section 7.03 of the agreement outlines the conditions under which the firm may incur additional debt but does not include a leverage requirement).

${ }_{93}$ Stephen Choi, Market Lessons for Gatekeepers, 92 Nw. U. L. REV. 916, 918 (1998).

${ }^{94}$ Cheffins \& Armour, supra note 30, at 24. 
all else being equal a private equity-owned company should be able to borrow money on more favorable terms than a standalone company, due to its lower credit risk. (The claim is not that private equity portfolio companies on average obtain loans on better terms than other companies. Private equity-backed companies on the whole take on significantly more leverage than otherwise comparable companies, and are therefore riskier from a lender's perspective. All else being equal, this should entail worse loan terms for the borrower. Returning to the example above, the claim is instead that J.Crew could not have borrowed as much as it did under TPG had it remained a public company, or could only have done so on far less favorable terms.)

Several clarifications of this secondary claim are in order. First, what is meant by borrowing "on more favorable terms"? Simply that a private equity-owned company will either be able to borrow more money than its standalone counterpart (on otherwise the same terms), or that it will be able to borrow the same amount of money but with more borrower-friendly provisions, such as a lower interest rate, lower fees, a longer maturity, or less restrictive conditions, covenants, and events of default. ${ }^{95}$ If correct, the thesis entails that private equity firms provide the valuable function of lowering companies' cost of debt capital.

Second, "all else being equal" means that, other than with respect to their ownership (private equity-sponsored versus nonsponsored), the companies are identical from a creditor's perspective. In other words, we assume that at the time at which they are compared, the companies have identical operating and financial characteristics, identical types and amounts of debt in their capital structure, identical management and incentive plans for management, identical information about the company available to creditors, and so forth. These assumptions are not intended to approximate reality; ${ }^{96}$ they simply serve to isolate the effect of reputation on debt terms.

${ }^{95}$ Id. at 24; Masulis \& Thomas, supra note 71, at 256.

96 Private equity firms have substantially more leverage than otherwise comparable companies, and, when one compares them to public companies, they are thought to exhibit better governance and make less information available to creditors. Masulis \& Thomas, supra note 71, at 255-56; see Whitehead, supra note 15, at 664 (describing how less information is available about private borrowers than public). 


\section{B. Gatekeeping in the Financial Markets-A Framework}

Gatekeepers are broadly understood to be private actors that can prevent companies' misconduct in a specific market. ${ }^{97}$ The precise definition of a gatekeeper is somewhat elusive, however, as the gatekeeper literature has evolved in two directions. The first, associated with Reinier Kraakman, defines a gatekeeper as any party from whom a company needs a good or service, and who can prevent the company's misconduct simply by refusing to provide it. ${ }^{98}$ The second, associated primarily with John Coffee, defines a gatekeeper as "a reputational intermediary who provides verification or certification services to investors." "99 The first is broad enough to cover all types of markets and is agnostic as to the gatekeeper's incentive for preventing company misconduct — on this view, any party from whom the company needs a good or service can be made a gatekeeper, simply by imposing liability on such party for the company's misconduct. ${ }^{100}$ The second pertains only to the financial markets and stipulates that the gatekeeper's incentive to intervene is its reputation in the market with investors. ${ }^{101}$ For the remainder of this Article, the term "gatekeeper" will mean a reputational intermediary in one or more financial markets, in accordance with Coffee's understanding of the term.

The key to identifying gatekeepers is understanding why gatekeepers are needed in the first place. In the financial markets, dispersed investors have imperfect information about companies and limited control over them, and companies can exploit this asymmetry by misrepresenting their quality to investors or by engaging in misconduct undetected. Because investors are aware of this possibility ex ante, they will invest less and will do so on less

97 Reinier H. Kraakman, Gatekeepers: The Anatomy of a Third-Party Enforcement Strategy, 2 J.L. ECON. \& ORG. 53, 54 (1986).

${ }^{98} I d$. at 53.

${ }^{99}$ John C. Coffee, Jr., Gatekeeper Failure and Reform: The Challenge of Fashioning Relevant Reforms, 84 B.U. L. REV. 301, 309 (2004). Though this version of the gatekeeper definition is associated with John Coffee, the concept of a reputational intermediary originated with Ron Gilson and Reinier Kraakman. Ronald J. Gilson \& Reinier H. Kraakman, The Mechanisms of Market Efficiency, 70 VA. L. REV. 549, 618 (1984).

${ }^{100}$ Kraakman, supra note 97, at 61-66.

${ }^{101}$ Coffee, supra note 99, at 302. 
company-favorable terms than they would in the presence of perfect information and control. ${ }^{102}$ This makes both investors and companies worse off. ${ }^{103}$ A gatekeeper can step in to bridge this gap between investors and companies by staking its reputation as to companies' quality or conduct, as applicable. ${ }^{104}$ Gatekeeping therefore provides the socially valuable function of facilitating a more efficient level of investment. ${ }^{105}$

The gatekeeper literature offers an array of different frameworks and approaches for identifying gatekeepers and assessing their performance. ${ }^{106}$ I distill these into a simple framework comprising three basic requirements for a gatekeeper in a financial market:

(1) the market at issue must exhibit some inefficiency resulting from information and/or control problems between companies and investors; ${ }^{107}$

(2) the proposed gatekeeper must have the incentive to mitigate the problem $(\mathrm{s}) ;{ }^{108}$ and

(3) the proposed gatekeeper must have the ability to mitigate the problem(s). ${ }^{109}$

102 See Choi, supra note 93, at 933.

${ }^{103}$ Id. at 933-34 (explaining "social welfare is reduced relative to the perfect information case because purchasers willing to purchase highquality goods at above the cost of production are unable to do so").

${ }^{104}$ Coffee, supra note 99 , at 308.

105 See Choi, supra note 93, at 946-47.

106 See generally Choi, supra note 93; Coffee, supra note 99; Ronald J. Gilson, The Devolution of the Legal Profession: A Demand Side Perspective, 49 MD. L. REV. 869 (1990); Assaf Hamdani, Gatekeeper Liability, 77 S. CAL. L. REV. 53 (2003); Howell E. Jackson, Reflections on Kaye, Scholer: Enlisting Lawyers To Improve the Regulation of Financial Institutions, 66 S. CAL. L. REV. 1019 (1993); Sung Hui Kim, Gatekeepers Inside Out, 21 GEO. J. LEGAL ETHICS 411 (2008); Frank Partnoy, Barbarians at the Gatekeepers? A Proposal for a Modified Strict Liability Regime, 79 WASH. U. L.Q. 491 (2001); Andrew F. Tuch, Multiple Gatekeepers, 96 VA. L. REV. 1583 (2010).

107 Tuch, supra note 106, at 1594-95.

${ }^{108}$ Kraakman, supra note 97, at 62.

${ }^{109} \mathrm{Kim}$, supra note 106 , at 414 . In addition, it cannot be the case that all of the companies in the market have the exact same ex ante quality and ex post 
This framework will be applied in Part III to private equity firms' role in the debt markets.

\section{Broadening the Gatekeeper Concept}

By now, it will have occurred to the reader that private equity firms are atypical candidates for gatekeeping. Indeed, much of the gatekeeper literature either implicitly or explicitly assumes that gatekeepers are independent professional organizations, ${ }^{110}$ which have the power to prevent companies' misconduct because they provided them with a needed service. ${ }^{111}$ The conception of gatekeepers as third-party service providers is plain in the most commonly proffered example of gatekeeping, namely the requirement that start-up companies obtain comfort letters from nationally-recognized accounting firms in order to complete an IPO. ${ }^{112}$

A private equity firm is clearly not a third party from the perspective of its portfolio companies. As the entity with sole control of the company, it may well be the consummate insider. Nor is it fundamentally a service provider to its companies. In the context of debt financing, the company does not seek out the private equity firm to negotiate its debt; rather, the private equity firm causes the company to take on debt in the first place. ${ }^{113}$

Is being a strictly independent third party a fundamental requirement for gatekeeping or merely a common characteristic of gatekeepers in practice? From a functional perspective, there is no reason why insiders should be dismissed out of hand as potential gatekeepers. So long as they satisfy the fundamental goal of financial-market gatekeeping-limiting the degree to which companies exploit their information advantage over investors-the terminology can and should be expanded to cover insiders. Accordingly, recent work argues that even inside counsel can act as

performance. See generally Choi, supra note 93 . This assumption is clearly satisfied in practice.

${ }^{110}$ Coffee, supra note 99, at 302 (describing gatekeepers as "independent professionals").

${ }^{111}$ Gilson, supra note 106, at 883 (claiming that a gatekeeper must provide "some service which the wrongdoer must have to accomplish his goal").

${ }^{112}$ Coffee, supra note 99, at 302.

${ }^{113}$ APPELBAUM \& BATT, supra note 3, at 13-15. 
gatekeepers for their companies, under certain conditions. ${ }^{114}$

Strict independence is not necessary for successful gatekeeping; all that is required is a sufficient divergence of the gatekeeper's incentives and those of management, so that the baseline incidence of company misconduct is reduced. ${ }^{115}$ Although private equity firms closely monitor the officers of their portfolio companies, they do not actually exercise management of the day-today business of the company, leaving that instead to hired officers. ${ }^{116}$ While such managers might benefit from a one-time event in which they mislead creditors, for example, the private equity firm will benefit less, due to the long-term reputational harm from doing so. ${ }^{117}$ Thus, the incentives of private equity firms do not perfectly overlap with those of management, and this mismatch enables private equity firms to act as gatekeepers, by constraining management's behavior toward creditors to at least some degree.

To conclude, whether private equity firms can be referred to as gatekeepers should depend only on whether they are successful at the task, which is addressed in the following three Parts.

\section{Private Equity Gatekeeping: Application}

This Part III applies the gatekeeping framework introduced above to demonstrate that private equity firms act as gatekeepers in the debt markets with respect to their portfolio companies. The three requirements for successful gatekeeping - the existence of information and/or control problems limiting investment in the market and of a gatekeeper with both the incentive and the ability to mitigate these problems - are satisfied because: (1) the debt markets suffer from the agency costs of adverse selection ex ante and moral hazard ex post, which lenders are increasingly unable to control on

${ }^{114}$ Gilson, supra note 106, at 883; Kim, supra note 106, at 413.

115 See Coffee, supra note 99, at 304.

116 Stephanie R. Breslow \& Phyllis A. Schwartz, Private Equity FUNDS: FORMATION AND OPERATION 1:19-1:20 (Practising Law Institute 2013).

${ }^{117}$ I readily concede that the degree to which a gatekeeper is independent from the company will likely impact the calculus involved in determining whether to impose gatekeeper liability and in what form, but it is less relevant for pure market-based gatekeepers, such as private equity firms. 
their own; ${ }^{118}$ (2) as repeat players in the debt markets, private equity firms have the reputational incentive to exert efforts to mitigate these agency costs in their portfolio companies; ${ }^{119}$ and (3) private equity firms have the ability to mitigate these agency costs through their extensive knowledge of, and control over, these companies. ${ }^{120}$ Each of these three requirements is discussed in turn below.

\section{A. The Agency Costs of Debt}

That some degree of information asymmetry exists between companies and investors is uncontroversial: even with the largest public companies, which are required by law to disclose all "material" information to the public, may have a long and wellestablished track record, and whose stock and bonds are heavily traded, management will always know more about their companies'

prospects than will investors. ${ }^{121}$ Separately, passive investors exercise only imperfect control over companies. ${ }^{122}$ In the debt markets specifically, information asymmetry and limited investor control together give rise to two well-known sources of inefficiency, referred to collectively as the agency costs of debt. ${ }^{123}$

\section{Adverse Selection}

First, information asymmetry between borrowing companies and creditors leads to adverse selection among borrowers. ${ }^{124}$ If creditors are unable to perfectly discern a borrower's quality, they will offer loans to borrowers on terms that correspond to the average expected quality of borrowers in the market. ${ }^{125}$ Because high-quality borrowers are disadvantaged by this outcome while low-quality borrowers benefit from it, higher-quality borrowers may begin to exit the market while lower-quality borrowers will try to borrow more

\footnotetext{
${ }^{118}$ Albert Choi \& George Triantis, Market Conditions and Contract Design: Variations in Debt Contracting, 88 N.Y.U. L. REV. 51, 62, 68 (2013).

${ }^{119}$ Masulis \& Thomas, supra note 71, at 239.

${ }^{120} \mathrm{Id}$. at $253-54$.

${ }^{121} \mathrm{Id}$. at $246-47$.

${ }^{122}$ Lee Harris, A Critical Theory of Private Equity, 35 DEL. J. CORP. L. 259, 268-69 (2010).

${ }_{123}$ Jensen, supra note 75 , at 323.

${ }^{124}$ JeAn Tirole, The TheORY OF CORPorate FinANCE 2 (2006).

${ }^{125}$ Choi, supra note 93 , at 933.
} 
than they otherwise would. ${ }^{126}$ As the quality of borrowers in the market declines, lenders will respond by offering less favorable debt terms to borrowers, to reflect the change in average borrower quality. ${ }^{127}$ This will cause still more high-quality borrowers to exit the market and debt terms to further worsen, and so on. ${ }^{128}$ The upshot for borrowing companies is that, as a whole, they will receive fewer/smaller loans and on worse terms than they would if creditors had perfect information about their quality. ${ }^{129}$

\section{Moral Hazard}

The second agency cost of debt is that of borrower moral hazard. While adverse selection arises ex ante (before the money has been loaned), moral hazard arises ex post. Once borrowers have the money in hand, they have incentives to act in ways that favor their shareholders over their creditors. ${ }^{130}$ This problem, also referred to as the shareholder-creditor conflict, results from shareholders and creditors having differing claims on a company's assets. ${ }^{131}$ As the residual claimants of a corporation, shareholders receive all of the upside from corporate actions (once liabilities have been repaid), whereas creditors can, at most, get back the amount that they loaned, plus the agreed-upon interest and fees. ${ }^{132}$ For both groups, losses are limited to the money they put into the company (which, in the case

\footnotetext{
${ }^{126}$ Whitehead, supra note 15 , at 664-66.

127 See Paul M. Healy \& Krishna G. Palepu, Information Asymmetry, Corporate Disclosure, and the Capital Markets: A Review of the Empirical Disclosure Literature, 31 J. ACC. \& ECON. 405, 408 (2001).

128 See Choi, supra note 93, at 943-945 (providing a simple model of adverse selection applicable to any market in which company quality varies).

${ }^{129}$ See TIROLE, supra note 124 , at 114 for a model of credit rationing. Under certain conditions, adverse selection can cause all higher-quality companies/ producers to exit the market, leaving only low-quality ones. George A. Akerlof, The Market for "Lemons": Quality Uncertainty and the Market Mechanism, 84 Q.J. ECON. 488, 495 (1970).

130 George Triantis, A Free-Cash-Flow Theory of Secured Debt and Creditor Priorities, 80 VA. L. REV. 2155, 2158 (1994).

${ }^{131} \mathrm{Id}$.

132 Edward B. Rock, Adapting to the New Shareholder-Centric Reality, 161 U. PA. L. REV. 1907, 1927 (2013).
} 
of the company's management, may be nothing at all). ${ }^{133}$ As a result, shareholders have incentives to cause the company to divert wealth from creditors, for example, by pursuing excessively risky projects (particularly if the company is near insolvency), distributing assets to the shareholders as dividends, or issuing additional debt of the same or higher priority as that of its existing creditors. ${ }^{134}$

As with adverse selection, the existence of moral hazard results in borrowers obtaining less favorable debt terms ex ante. ${ }^{135}$

\section{Traditional Creditor Responses to Agency Costs}

Clearly, the presence of borrower adverse selection and moral hazard has not caused the corporate debt markets to unravel, largely because creditors have developed strategies to deal with these agency costs.

In the case of adverse selection, the traditional approach is for creditors to expend resources on screening the borrower prior to lending in order to more accurately discern the borrower's credit risk (and without relying solely on the borrower's good faith). ${ }^{136}$

${ }^{133}$ James C. Spindler, How Private is Private Equity, and at What Cost?, 76 U. CHI. L. REV. 311, 326 (2009).

${ }^{134}$ Clifford W. Smith, Jr. \& Jerold B. Warner, On Financial Contracting: An Analysis of Bond Covenants, 7 J. Fin. ECON. 117, 118-19 (1979).

${ }^{135}$ The finance literature lacks a comprehensive model for how debt terms are determined. Victoria Ivashina \& Zheng Sun, Institutional Demand Pressure and the Cost of Corporate Loans, 99 J. FIN. ECON. 500, 510 (2011) (stating "the current literature does not have a defined set of loanpricing factors"). Yet the primary determinant of a borrower's debt terms is undoubtedly its credit risk (that is, the likelihood that creditors will recover the amount that they lend to the borrower). OCC, COMPTROLLER's HANDBOOK: RATING CREDIT RISK 21 (2001). A borrower's credit risk is for the most part a function of the operational characteristics and performance of the borrower (cash flow, industry sector, etc.), the capital structure of the borrower (in particular, its leverage), and features of the proposed debt itself (priority, security, guarantees, maturity). Id. at 21-22. Beyond credit risk, other determinants of a borrower's debt terms should include liquidity risk (the ease with which a creditor can transfer its interest in the borrower's debt to another creditor), prevailing market-wide yields, transaction costs, relative bargaining power between the borrower and the creditors, and so forth. Id.

${ }^{136}$ TIROLE, supra note 124 , at 87-88. 
Creditors screen borrowers primarily in two ways: (1) by performing due diligence on the company prior to lending and (2) by maintaining long-term lending relationships with their borrowers. ${ }^{137}$ In the case of moral hazard, creditors have primarily employed two methods to limit borrower misconduct: (1) direct monitoring and (2) debt covenants. ${ }^{138}$

Monitoring. Under the traditional model of bank lending, in which a single bank extends the loan to the borrowing company and holds the loan to maturity, the bank has both the incentive and the ability to monitor the borrower closely. ${ }^{139}$ Banks have thus historically had a cost advantage in monitoring borrowers, making banks the intermediary of choice to whom the task of direct monitoring was delegated. ${ }^{140}$

Debt Covenants. All corporate borrowings are subject to covenants made by the company to its creditors. ${ }^{141}$ The term "covenants" here refers broadly to all of the contractual provisions in credit agreements, indentures, notes, and other debt contracts that restrict the borrower's activities or require it to take certain actions deemed desirable by its creditors. ${ }^{142}$ The value of covenants to creditors (and thus to borrowers) is obvious when one recalls that there is no legal prohibition on companies favoring shareholders at the expense of creditors - quite the contrary. While shareholders are owed fiduciary duties by the directors ${ }^{143}$ and officers ${ }^{144}$ of the

${ }^{137}$ Id.; Whitehead, supra note 15, at 665-66.

${ }^{138}$ Whitehead, supra note 15 , at 664-65.

${ }^{139}$ Id. at 651-53.

140 Douglas W. Diamond, Financial Intermediation and Delegated Monitoring, 51 REV. ECON. STUD. 393, 393 (1984).

${ }^{141}$ See TIROLE, supra note 124, at 105 (describing covenants as "the heart of a loan agreement").

${ }^{142} I d$. at 83-86, 103-05. Thus, "covenants" in this informal sense will include typical categories of debt contract provisions such as financial covenants, negative covenants, affirmative covenants, events of default, representations and warranties, and borrowing conditions precedent. Id.

${ }^{143}$ See, e.g., Emerald Partners v. Berlin, 787 A.2d 85, 90-91 (Del. 2001) (affirming that directors' duty of care may not be waived in Delaware); Sutherland v. Sutherland, No. 2399-VCL, 2009 WL 857468, at*4 (Del. Ch. Mar. 23, 2009) (holding the same with respect to directors' duty of loyalty).

${ }^{144}$ E.g., Gantler v. Stephens, 965 A.2d 695, 708, 709 n.37 (Del. 2009) (explicitly recognizing that officers of Delaware corporations have fiduciary duties to shareholders). 
corporation, creditors are not. ${ }^{145}$ Thus, borrowers are not liable for misconduct toward their creditors unless they voluntarily assume contractual liability, which is the principle behind covenants. ${ }^{146}$

\section{The Decline of Monitoring and Covenants}

Today, however, monitoring and covenants are receding in the debt markets. Public debt has always relied less heavily on monitoring and covenants than has private debt, for reasons that will become clear below. ${ }^{147}$ Yet as a result of sweeping changes to the private debt markets over the last three decades, monitoring and covenants are declining in the private market as well, which makes up the vast majority of corporate debt. ${ }^{148}$

The driving force is the rapid adoption of the practice of loan syndication, in which corporate loans, rather than being held by a single bank until maturity, are instead funded from the outset by large numbers of creditors. ${ }^{149}$ Post-issuance, syndicated loans may be traded to still more creditors on an increasingly liquid secondary

${ }^{145}$ The lone exception to this general rule applies if the company becomes insolvent, in which case the directors' fiduciary duties are for the benefit of creditors. See N. Am. Catholic Educ. Programming Found. v. Gheewalla, 930 A.2d 92,101-03 (Del. 2007); Geyer v. Ingersoll Publ'ns, 621 A.2d 784, 787-88 (Del. Ch. 1992); Credit Lyonnais Bank Nederland, N.V. v. Pathe Commc'ns Corp., Civ. A. No. 12150, 1991 WL 277613, at*1155-57 (Del. Ch. Dec. 30, 1991).

${ }^{146}$ The theory behind these provisions was first expounded in a seminal article relating to bond covenants. Smith \& Warner, supra note 134, at 117. Lenders ask for, and borrowers covenant to abide by, such provisions because they maximize the value of the company by optimally addressing moral hazard. The tradeoff is between (1) giving management free reign to extort money from lenders (which would cause lenders not to extend any credit to the company, or only at exorbitant rates) and (2) giving lenders $100 \%$ control of the company (which would lead to poor performance). Id.

${ }^{147}$ See generally Whitehead, supra note 15.

${ }^{148}$ Id. at 662 (describing the increase in "cov-lite" loans since 2005). For ease of presentation, throughout this discussion the term "public debt" should be thought of as publicly traded bonds, while "private debt" should be thought of as senior corporate loans (or "bank debt," as practitioners refer to it).

${ }^{149} I d$. For a description of the loan syndication process, see Ivashina \& Sun, supra note 135 , at $503-08$. 
market, in which banks now represent a small minority. ${ }^{150}$ Corporate loans, once the near-exclusive province of banks, are now routinely held by an ever-widening array of financial institutions, including mutual funds, hedge funds, insurance companies, finance companies, pension funds, foreign institutions, and securitization vehicles, such as collateralized loan obligation ("CLO") funds. ${ }^{151}$ While a syndicated loan is still typically negotiated between the borrowing company and a single bank, known as the "lead arranger," 152 it is ultimately funded by a large number of lenders (the "syndicate") gathered by the lead arranger. ${ }^{153}$ By the end of the syndication process, the lead arranger may end up holding only a very small piece of the loan or none at all. ${ }^{154}$

Decline in monitoring. What happens to the monitoring function of creditors when bank debt is syndicated? As the number

150 GlenN Yago \& Donald McCarthy, Milken Inst., The U.S. LEVERAGED LOAN MARKET: A PRIMER 26-27 (2004).

${ }^{151}$ Bartlett, supra note 52, at 2013; YAGO \& MCCARTHY, supra note 150, at 26-27.

152 Lead arranger positions for large syndicated loans tend to be monopolized by large investment or commercial banks. Barry Bobrow, Mercedes Tech \& Linda Redding, The Primary Market, in THE HANDBOOK OF LOAN SYNDICATIONS AND TRADING 155, 172 (Allison Taylor \& Alicia Sansone eds., 2006) (stating that the top three lead arrangers together covered $47 \%$ of the total syndicated loan market in 2005); Anil Shivdasani \& Yihui Wang, Did Structured Credit Fuel the LBO Boom?, 66 J. FIN. 1291, 1306 (2011) (finding that after 2004, the top ten LBO lenders held a 94\% share of the market in LBO lending). According to the Loan Pricing Corporation, in the first quarter of 2012, the top three bookrunners held $44 \%$ of the market share. Press Release, Loan Prod. Co., Refinancings Drive 1Q12 Leveraged Lending, M\&A Absent (Apr. 5, 2012), available at https://www.loanpricing.com/2012/07/refinancings-drive-1q12-leveragedlending-ma-absent/.

${ }^{153}$ Under the traditional one-bank-one-borrower model, the bank acts as an intermediary between the borrower and its ultimate creditors, the bank's depositors. Diamond, supra note 140, at 393. Under the syndication model, the lead arranger serves as the intermediary between the borrower and the rest of the syndicate - a form of secondary intermediation. Katerina Simons, Why Do Banks Syndicate Loans?, NEW ENG. ECON. REV. 45, 46 (Jan./Feb. 1993).

154 Jian Cai, Competition or Collaboration? The Reciprocity Effect in Loan Syndication 1 (Fed. Reserve Bank of Cleveland, Working Paper No. 0909R, 2010), available at http:/www.clevelandfed.org/research/workpaper/ 2009/wp0909r.pdf. 
of creditors grows, creditors' incentives to monitor the borrower decline, due to a familiar free-rider problem. ${ }^{155}$ Any given member of a large lending syndicate will have little incentive to monitor the borrower because direct monitoring is costly, and any benefit therefrom will have to be shared among all of the creditors. ${ }^{156}$ Each syndicate member will thus prefer to free-ride on the efforts of others. Therefore, the growth of syndication is predictably accompanied by a decline in the direct monitoring of borrowers.

Nor can this void in monitoring be filled simply by delegating the task to the lead arranger of the syndicate. ${ }^{157}$ To begin with, lead arrangers are equally subject to the free-rider problem in that the benefits of their monitoring would be shared with all lenders. (Recall that lead arrangers may hold only a small portion of the loans that they arrange, if any.) Because the results of monitoring effort on the lead arranger's part are particularly difficult to observe and measure, the other syndicate members cannot simply compensate the lead arranger to monitor the borrower on their behalf. ${ }^{158}$ Thus, the growth of syndication has gone hand in hand with a decline in the monitoring of borrowers.

Decline in covenants. The move from a single-bank to a loan-syndication model introduces new transaction costs to the

155 Shivdasani \& Wang, supra note 152, at 1315-16; Hugh Thomas \& Zhiqiang Wang, The Integration of Bank Syndicated Loan and Junk Bond Markets, 28 J. BANKING \& FIN. 229, 306 (2004). For the original description of collective action problems, see Mancur Olson, Jr., The Logic of Collective Action: Public Goods and the Theory of Groups, in HARVARD ECONOMIC STUDIES 124 (1965).

${ }^{156}$ Amir Sufi, Information Asymmetry and Financing Arrangements: Evidence from Syndicated Loans, 62 J. FIN. 629, 641-42 (2007). It is for this reason that publicly traded bonds do not involve creditor monitoring. Yakov Amihud, Kenneth Garbade \& Marcel Kahan, A New Governance Structure for Corporate Bonds, 51 STAN. L. REV. 447, 469 (1998-1999) (explaining that a "bond indenture will contain few covenants; and those that appear entail little monitoring").

${ }^{157}$ Thomas \& Wang, supra note 155, at 306 (stating that the lead arranger for a syndicated loan is not tasked with monitoring the borrower, but rather performs a relatively mechanical role with very little discretion).

${ }^{158}$ Sufi, supra note 156, at 641-42. Again, the analogy to publicly traded bonds is a useful one. The trustee of a bond issuance is paid compensation by the bondholders, yet for the most part performs only a ministerial role. Steven L. Schwarcz \& Gregory M. Sergi, Bond Defaults and the Dilemma of the Indenture Trustee, 59 ALA. L. REV. 1037, 1044 (2008). 
corporate loan market: the same renegotiation and holdout costs that arise with widely dispersed public bonds. ${ }^{159}$ As the number of creditors holding a loan increases, so do the costs of making changes to the loan terms due to a collective action problem among the lenders. ${ }^{160}$ If the borrower needs to obtain a waiver or an amendment to the loan terms, it must obtain the consent of a large group of disparate and unrelated lenders, instead of negotiating with a single bank. ${ }^{161}$ This may prove either impossible or prohibitively expensive, even though all parties would prefer the proposed change to the loan terms to the alternative of bankruptcy, or it may prevent the borrower from pursuing a value-creating transaction. ${ }^{162}$ Because this collective action problem can decrease the value of the company, lenders rationally agree ex ante to more permissive covenants in the credit agreement in order to decrease the likelihood that the borrower will default on the loan or require other changes to its terms. ${ }^{163}$ This is exactly what occurs in the public debt markets, where disparate and uncoordinated ownership entails substantially looser covenants. ${ }^{164}$

159 See Amihud et al., supra note 156, at 467-78 (describing transaction costs associated with public bonds).

${ }^{160}$ Id. at $459-60$.

${ }^{161}$ Robert O. Wienke, Loan Syndications and Participations: Trends and Tactics, 9 COM. LENDING REV. 4, 22 (1993-1994).

${ }^{162} I d$. at 24. In addition, the creditor that holds out the longest is likely to get the biggest payout from the borrower, so all creditors have an incentive to delay. John C. Coffee, Jr. \& William A. Klein, Bondholder Coercion: The Problem of Constrained Choice in Debt Tender Offers and Recapitalizations, 58 U. CHI. L. REV. 1207, 1238 (1991).

${ }_{163}$ Alan M. Christenfeld \& Barbara M. Goodstein, Covenant-Lite Loans Rise Again, 250 N.Y. L.J. 67 (2013); Stephen Foley, Covenant Lite Loans Lose Their Stigma in the Hunt for Yield, FIN. TIMES, June 1, 2013, at 12.

${ }^{164}$ Christenfeld \& Goodstein, supra note 163. A simple example may help illustrate the point. Assume that a company borrows from a single bank, and that the credit agreement contains a financial covenant requiring the borrower not to exceed a leverage ratio of 4 to 1 at any time while the loan remains outstanding. This covenant may be set at a slightly optimistic level, with the implicit understanding that the borrower can return to the bank to negotiate a new covenant level if it ends up proving necessary. Now, if the company were to refinance this loan with a syndicated loan funded by a large number of creditors, the new credit agreement could conceivably require only that the borrower not exceed a leverage ratio of 3 to 1 . The more permissive covenant level in this instance reflects the creditors' understanding of the inefficiencies involved in renegotiating credit 
Thus, the onset of loan syndication has required a loosening of covenants in borrowers' credit agreements. ${ }^{165}$

The benefits of loan syndication and secondary trading are obvious: greater diversification for lenders and greater access to capital for borrowers. ${ }^{166}$ Yet syndication exacerbates adverse selection and moral hazard in the loan market by prompting a decline in monitoring and covenants. ${ }^{167}$ The key implication of this fundamental change in the nature of corporate lending is that private equity's gatekeeping role in the debt markets should be increasingly valuable to lenders. If private equity firms can fill the monitoring void left by lenders, their portfolio companies will reap the benefits of cheaper debt.

\section{B. Private Equity Firms' Incentive to Mitigate Agency Costs}

In order for private equity firms to qualify as gatekeepers, creditors must have some assurance that private equity firms will exercise efforts to mitigate the agency costs of debt. This sub-part argues that, because they are high-volume, repeat players in the debt markets, private equity firms have strong reputational incentives to ensure that their portfolio companies behave as "good" borrowers. Therefore, they can credibly commit to mitigating both adverse selection (by acting as certification intermediaries) and moral hazard (by acting as monitoring intermediaries) in their portfolio companies.

agreement terms, which may more than offset the benefits of tighter control of the borrower.

${ }^{165}$ Cem Demiroglu \& Christopher M. James, The Role of Private Equity Group Reputation in LBO Financing, 96 J. FIN. ECON. 306, 306-09 (2010). For example, in their sample of 183 going-private LBOs, the authors found that no private equity firm had a "covenant-lite" loan (an exceptionally borrower-favorable type of loan) before 2004, while nearly $60 \%$ did through part of 2007. Id. at 315 . In volume terms, they report that covenantlite loans in LBO financings grew from $\$ 0$ in 2000 to over $\$ 93$ billion in the first half of 2007. Id. at 307.

${ }_{166}$ See Bobrow et al., supra note 152, at 176.

${ }^{167}$ Miguel Meuleman, Mike Wright, Sophie Manigart \& Andy Lockett, Private Equity Syndication: Agency Costs, Reputation and Collaboration, 36 J. Bus. Fin. \& ACCT. 616, 620 (2009). 


\section{Repeat Players}

Though private equity firms themselves do not borrow for acquisitions, they are nonetheless high-volume, repeat players in the debt markets. ${ }^{168}$ On behalf of their many portfolio companies, they negotiate more frequent borrowing, and of greater amounts, than do standalone companies. ${ }^{169}$ A single private equity firm should generate significantly more borrowing volume than a standalone company because it manages several borrowing companies at once, each of which is more highly leveraged than a typical standalone company. ${ }^{170}$

First, a typical private equity-owned portfolio company borrows far more than an otherwise identical standalone company. ${ }^{17}$

${ }^{168}$ Ivashina \& Kovner, supra note 13 , at 2466.

169 See id. at 2462-63 (explaining that "LBO firms are important clients for banks because of the frequency and scale of their transactions").

${ }^{170}$ I propose yet another reason why the volume of a private equity firm's borrowing should outweigh that of a standalone company: one might expect LBO portfolio companies to refinance their loans more frequently than other companies. Because they are more highly leveraged, LBO portfolio companies are more sensitive to interest rates and should therefore seek to refinance more often as the prevailing market interest rate margin changes. Anne-Sylvaine Chassany, Buyout Groups Set Refinancing Record, FIN. TIMES, Sept. 18, 2013, at 13 (describing an increase in private equity refinancings in an attempt to "lock into low interest rates"). Further, a portfolio company's debt must be refinanced when the company is ultimately sold by the LBO fund (due to a standard credit agreement provision requiring the repayment of the loan upon a change of control of the borrower), which occurs relatively frequently. See Wight et al., supra note 28, at 346, 350-51. Indeed, all LBO funds have a limited lifespan of, say, ten years. Kaplan \& Strömberg, supra note 8, at 123. If a portfolio company is acquired in year seven of the fund's existence, and the debt incurred in connection with the acquisition has a maturity of, say, six years, the debt will have to be refinanced only five years into its term at the latest.

171 Recent work found that out of a sample of 1157 leveraged buyout companies and matched public companies, the median leverage ratio (measured as the ratio of net debt to EBITDA) for private equity-owned companies was 0.70 , as compared to 0.35 for public companies. Ulf Axelson, Tim Jenkinson, Per Strömberg \& Michael S. Weisbach, Borrow Cheap, Buy High? The Determinants of Leverage and Pricing in Buyouts, 68 J. FIN. 2223, 2239 (2013) (showing in Table IV "the median values of net debt . . . to enterprise value ... and net debt to earnings before interest, 
Although it is commonly accepted that private equity-owned companies are highly leveraged, less thought has been given to why this is so. Recent contributions to the literature suggest two explanations: first, that debt provides private equity firms with an advantage in bidding for target companies, ${ }^{172}$ and second, that the standard allocation of profits between private equity firms and their investors creates incentives for private equity firms to maximize their portfolio companies' leverage. ${ }^{173}$ Thus, when a private equity fund acquires a company, it causes the company to incur debt on the order of $50-80 \%$ of total enterprise value and will seek to maintain as high a level of debt as possible throughout its term of ownership. ${ }^{174}$ In contrast to typical companies, private equity-sponsored companies borrow as much as the market will allow, and they borrow independently of their operational need for debt. ${ }^{175}$ In contrast, public companies (for example) tend to borrow relatively little and primarily for operational reasons. ${ }^{176}$

taxes, depreciation, and amortization" for a sample of LBOs and public companies).

${ }^{172}$ See generally Bartlett, supra note 52. Note that this explanation does not account for the well-documented fact that private equity-owned companies deliberately maintain very high leverage ratios following their initial acquisition.

${ }^{173}$ Ulf Axelson, Per Strömberg \& Michael S. Weisbach, Why Are Buyouts Levered? The Financial Structure of Private Equity Funds, 64 J. FIN. 1549, 1555 (2009).

${ }^{174} I d$.

${ }^{175}$ Id.; Axelson, Jenkinson, Strömberg \& Weisbach, supra note 171, at 4. The latter demonstrates that the amount of leverage in private equity-owned companies is completely unrelated to that in comparable public companies, and that such leverage is chosen for entirely different reasons. The authors describe the pattern of leverage in LBO portfolio companies and public companies as the inverse of one another. Axelson, Jenkinson, Strömberg \& Weisbach, supra note 171, at 4.

${ }^{176}$ Operational reasons for borrowing include the need to even out the cash flows of a highly seasonal business or to make a planned acquisition. Public companies borrow comparatively little for a variety of reasons. First, they are subject to the well-recognized agency problem that management has incentives to avoid the excessive monitoring and control by creditors that is traditionally thought to accompany corporate loans. Jensen, supra note 75 , at 323-25. One manifestation of this is public company management's preference for having excess free cash on hand for self-interested reasons, as opposed to operating leanly as high leverage would require. Id. Second, risk-averse managers should be reluctant to incur debt: as leverage 
Second, the volume of borrowing is tipped even further toward private equity when one compares a given private equity firm to a given standalone company. A private equity firm often manages several funds at once, each of which owns several portfolio companies. ${ }^{177}$ Aggregating all of the borrowing of a given private equity firm's portfolio companies, it becomes clear that a private equity firm will be active in the debt markets more frequently and for greater amounts than would the management of a single company comparable in size to one of the private equity firm's portfolio companies. Thus, the sheer volume of borrowing by private equity firms makes it appropriate to view them as being involved in repeated game with creditors in the debt markets.

A concrete example may help to illustrate the disparity in borrowing size and frequency between a standalone company and a private equity firm. Kohlberg Kravis Roberts \& Co. L.P. ("KKR"), the largest private equity firm in the world, led the leveraged acquisition of Del Monte Corporation on March 8, 2011. ${ }^{178}$ Until it was acquired by KKR, Del Monte had been operating as a public company since February 1999. ${ }^{179}$ Using datasets from Thomson Reuters LPC's DealScan database, Table 1 below compares the U.S. syndicated loan transactions completed by Del Monte during its time as a standalone, publicly traded corporation to those completed by KKR on behalf of its various portfolio companies during the same period. While Del Monte completed only six syndicated loan deals during the relevant twelve-year period for a total of $\$ 6.1$ billion,

increases, so does the company's risk of insolvency, and thus the risk that managers might lose their jobs. Id. Lastly, my own view is that public companies may also simply grow out of their debt. If a company performs well, its EBITDA increases, and its leverage ratio therefore decreases naturally unless new debt is incurred. Yet, unlike a private equity-sponsored company, a public company is less likely to incur additional debt in that case because it does not face the same constant pressure to maximize leverage (discussed above) as private equity firms do.

${ }^{177}$ Harry Cendrowski \& Adam A. Wadecki, Introduction to Private Equity, in Private Equity History, GOVERnANCE, AND OPERATIONS 3, 6-8 (2d ed. 2012).

${ }^{178}$ Del Monte Corporation, Annual Report (Form 10-K), at 2 (June 15, 2011), available at http://www.sec.gov/Archives/edgar/data/1259045/ 000119312511189323/d10k.htm [hereinafter Del Monte 10-K].

179 Our History, Del MONTE FoODS, http://www.delmontefoods.com/ company/default.aspx?page $=$ oc_ourhistory (last visited Nov. 22, 2013). 
KKR completed ninety-eight for a total of $\$ 176.2$ billion. ${ }^{180}$

Table 1. Borrowing Comparison: KKR vs. Del Monte (Pre-LBO)

U.S. syndicated loan deals completed between February 1999 and March 2011 by Del Monte Corporation and by all KKR portfolio companies.

\begin{tabular}{|l|l|l|}
\hline & \# of Deals & Aggregate Size \\
\hline Del Monte Corp. & 6 & \$ 6.1 billion \\
\hline KKR & 98 & $\$ 176.2$ billion \\
\hline
\end{tabular}

2. Effect on Incentives

\section{a. Reputation with Creditors Generally}

As repeat players in the debt markets, private equity firms have the reputational incentive to act as gatekeepers. ${ }^{181}$ As we have seen, the ability to borrow massive amounts of debt on good terms is the sine qua non of private equity. Because they are constantly seeking to obtain or refinance debt for one of their various portfolio companies, private equity firms have much to gain from dealing with creditors in good faith, and much to lose otherwise. ${ }^{182}$ Creditors have

${ }^{180}$ DealScan Report, THOMSON REUTERS LPC, https://www.loanpricing. com/products/solutions-for-the-primary-market/loanconnectordealscan/

(datasets on file with author). The case of Del Monte also illustrates the separate point that individual companies tend to take on substantially more debt once they are acquired by private equity firms. According to SEC filings, Del Monte's aggregate debt load increased from $\$ 1.26$ billion to $\$ 3.97$ billion in connection with its 2011 acquisition by KKR. Del Monte $10-\mathrm{K}$, supra note 178 , at 57.

${ }^{181}$ Rongbing Huang, Jay R. Ritter \& Donghang Zhang, Private Equity Firms' Reputational Concerns and the Costs of Debt Financing 3 (Oct. 24, 2013) (unpublished manuscript), available at http://papers.ssrn.com/ sol3/papers.cfm?abstract_id=2205720.

${ }_{182}$ Andrew Keay, Directors' Duties to Creditors: Contractarian Concerns Relating to Efficiency and Over-Protection of Creditors, 66 MoD. L. REV. 665, 667 (2003). 
the opportunity to observe the track record of a private equity firm's portfolio companies over time, which will affect the debt terms that the firm is able to negotiate for its companies in the future. ${ }^{183}$ Thus, private equity firms have strong incentives to ensure good borrowing behavior by their portfolio companies and thereby establish and maintain good reputations with creditors. ${ }^{184}$

In this regard, private equity firms' incentives diverge enough from those of the managers of their portfolio companies that they will behave differently toward creditors than management would at least some of the time. It is undeniable that a private equity firm, as the sole shareholder of its portfolio companies, would benefit in the short-term from any gains derived from misrepresentations or misconduct by one of its portfolio companies with respect to its creditors. ${ }^{185}$ Under normal circumstances, ${ }^{186}$ however, the long-term harm to the firm's reputation from such misconduct should outweigh the short-term benefit. This divergence between private equity firms' and management's incentives enables

${ }^{183}$ Ivashina \& Kovner, supra note 13, at 2464-67.

${ }^{184}$ This is not to say that examples of private equity errors in judgment or "misbehavior" towards lenders do not exist. For example, some dividendrecapitalization transactions initiated by private equity sponsors (in which the portfolio company borrows additional debt for the sole purpose of issuing a dividend to the private equity fund that owns it) have left portfolio companies with too little equity cushion, which eventually led to insolvency. A notable example is the 2004 bankruptcy of KB Toys, which occurred only twenty months after Bain Capital caused it to undergo a dividend-recapitalization. Bain Capital Buys Toys Unit of Consolidated Stores, N.Y. Times, Dec. 9, 2000, at C3; Nicholas Confessore, Christopher Drew \& Julie Creswell, Buyout Profits Keep Flowing to Romney, N.Y. TIMES, Dec. 18, 2011, at A1. Such missteps undoubtedly had a negative impact on the relevant private equity firms' ability to negotiate financing on good terms, at least in the short run. Conversely, private equity funds have on occasion contributed additional equity to their portfolio companies in order to avert or cure a default on their debt; information about such occurrences is rarely publicly available, but recent work demonstrates that private equity firms are more likely to do this than other owners when the company is in bankruptcy proceedings. Hotchkiss et al., supra note 54, at 23-24.

${ }^{185}$ See Davis, supra note 9, at 89 (suggesting that the "strip and flip" private equity trend is evidence that "despite the ability of private-equity sponsors to take a long-term view, they will not always do so").

${ }^{186}$ See infra Part V for limitations on private equity's gatekeeping role. 
private equity firms to serve as effective gatekeepers. ${ }^{187}$ Concern for their long-term reputation should thus cause private equity firms to exert efforts to mitigate the agency costs of debt in their portfolio companies.

In game-theory terms, private equity firms should behave quite differently in repeated game with creditors than in an end game. ${ }^{188}$ Appendix A hereto provides a theoretical model demonstrating this result, and the following simple numerical example illustrates the point. Assume that a private equity fund uses \$20 million of its own pooled cash to acquire a company, and that creditors lend an additional $\$ 80$ million, such that the enterprise value of the company is $\$ 100$ million at the outset. Assume next that due to an exogenous shock, the value of the company immediately declines to $\$ 80$ million. At this juncture, the company is exactly on the border of insolvency, having just enough to repay the creditors (assuming no interest or fees have accrued, for simplicity).

The company can now be viewed as having only two options. The first, Option A, is simply to use the remaining $\$ 80$ million to repay the creditors in full. The second, Option B, is to take on a risky project on the slim chance that it will turn things around for the company. Assume, for example, that the project has a $10 \%$ chance of increasing the company's value to $\$ 500$ million, and a $90 \%$ chance of decreasing the company's value to $\$ 0$. Option A is great for creditors, who get all of their money back, but bad for the private equity firm, which will lose its entire investment in the company. Option B, on the other hand, is disastrous for both creditors and the company itself, because the expected value of the firm is only $\$ 50$ million. From the private equity firm's perspective, however, Option B is actually more appealing than Option A; even though the most likely outcome is that the company's value will be entirely wiped out, there is still some possibility that the private equity firm will recover its investment and, in fact, profit from it.

In an end-game situation, then, the private equity firm would unquestionably pick the "bet-the-farm" Option B, even though it would leave creditors with nothing. However, in a repeated game, the private equity firm will have at least some incentive to select

187 See Coffee, supra note 99, at 309 (highlighting the importance of differing incentives between the gatekeeper and the companies it serves).

${ }^{188}$ See generally Daniel J.H. Greenwood, Democracy and Delaware: The Mysterious Race to the Bottom/Top, 23 YALE L. \& POLICY REV. 381 (2005) (analyzing incentives for managers in repeat game and end game scenarios). 
Option A. Even though the private equity firm loses everythingwith certainty - under Option A, by repaying creditors in full, it will preserve its reputation in the debt markets and thus its ability to borrow on good terms in future deals.

In sum, private equity firms can be characterized as repeat players in the debt markets, while standalone companies more closely resemble end-game players. ${ }^{189}$ As shown in the previous example and in Appendix A, this should have a material impact on the respective debt terms that private equity firms are able to negotiate with creditors.

\section{b. Reputation with Specific Creditors}

The previous section demonstrated how a private equity firm's reputation among creditors as a whole serves to mitigate the agency costs of debt and leads to more favorable debt terms for its portfolio companies. Yet private equity firms are repeat players not only with respect to creditors in general, but more importantly with respect to a small group of specifically identifiable creditors: the handful of major U.S. commercial and investment banks that specialize in arranging or underwriting leveraged loans. ${ }^{190}$

The incentive not to cheat is much stronger when a private equity firm deals with the same creditor (the "relationship bank") over and over again than when it deals with a different creditor each time, because the relationship bank should always know when the private equity firm has cheated it and immediately punish the private equity firm the next time it attempts to borrow. When different creditors are involved each time, however, the incentive not to cheat will depend on whether anyone other than the borrower and creditor

${ }^{189}$ Of course, the dichotomy between the two groups is not nearly so stark in practice. The most seasoned corporate issuers borrow fairly regularly, giving them at least some reputational stakes as well. The more accurate depiction is of a scale of reputational incentives, with the most established private equity firms lying at one end, start-up companies and insolvent companies on the other, and large-cap standalone corporate issuers that are frequent borrowers somewhere in the middle.

190 The U.S. market for lead arranger positions is highly concentrated, dominated by the largest investment and commercial banks. Shivdasani \& Wang, supra note 152, at 1306. 
at issue can discern whether cheating has occurred ${ }^{191}$ and, if so, how quickly that information is disseminated to other creditors. ${ }^{192}$ Thus, by virtue of their relationships with a very small set of specific banks, private equity firms have an even stronger incentive to maintain reputations for good borrowing behavior, and creditors have more reason to rely on such reputations. ${ }^{193}$

Table 2 below illustrates the importance of private equity firms' relationships with specific banks. It lists the aggregate number and amount of credit facilities negotiated by KKR with the largest U.S. banks. ${ }^{194}$ The data was compiled using Thomson Reuters LPC's

${ }^{191}$ In the gatekeeper context, Frank Partnoy makes a similar point when noting that the reputation market is not efficient because it is difficult to observe the reputational intermediaries' effort and to correctly link it to companies' performance. Frank Partnoy, Strict Liability for Gatekeepers: A Reply to Professor Coffee, 84 B.U. L. REV. 365, 366-67 (2004).

${ }^{192}$ A more precise illustration follows. Imagine that a private equity firm expects to borrow at times $T_{1}$ and $T_{2}$, and that the group of potential creditors includes A, B, C, etc. Assume the private equity firm borrows from $A$ at $T_{1}$. If it is likely to borrow from $A$ again at $T_{2}$, it will have a very strong incentive not to cheat $\mathrm{A}$ at $\mathrm{T}_{1}$ because $\mathrm{A}$ is highly likely to know that it has been cheated and to retaliate by offering worse loan terms (such as a higher interest rate) at $\mathrm{T}_{2}$. If, however, the private equity firm is equally likely to borrow from a different creditor at $\mathrm{T}_{2}$, its incentive not to cheat at $\mathrm{T}_{1}$ will be weaker because (1) the information concerning the private equity firm's actions at $T_{1}$ may not have reached the other creditors by $T_{2}$ and (2), even if it has, these creditors may not know with certainty whether such actions amounted to cheating by the private equity firm. (For example, if the private equity firm's portfolio company defaulted on its debt between $T_{1}$ and $\mathrm{T}_{2}$, the creditors may not be able to discern whether this was a result of misconduct by the private equity firm or of some event outside of the private equity firm's control). Thus, repeat interactions with the very same lender make it even less likely that the private equity firm will cheat.

${ }^{193}$ For a rare example in the corporate law literature noting the reputational advantages of private equity, see Whitehead, supra note 15, at 666-67 (explaining that " $[t]$ he private equity market is principally comprised of a limited group of participants that interact frequently, suggesting that a reputation as a 'good' borrower can have substantial and positive economic consequences"). For an empirical demonstration of the effect of repeated interactions between the borrower and the same lender, see generally Ivashina \& Kovner, supra note 13.

${ }^{194}$ Note that Table 2 covers only senior loans; if high-yield bonds were included the number of transactions with each bank group and aggregate amount would be significantly higher. 
DealScan database of syndicated loans. ${ }^{195}$

Table 2. KKR Bank Relationships: 1986-2011

Most frequent lead (or co-lead) arrangers for bank debt facilities of KKR-sponsored companies from March 1, 1986 through May 30, 2011. Includes only facilities denominated in U.S. dollars and syndicated in the U.S.

\begin{tabular}{|l|l|l|}
\hline Lender Group & $\begin{array}{l}\text { Facilities for KKR- } \\
\text { Owned Companies }\end{array}$ & Total Amount \\
\hline JP Morgan & 154 & $\$ 104,723,000,000$ \\
\hline Deutsche Bank & 141 & $\$ 86,223,298,224$ \\
\hline Citibank & 98 & $\$ 96,324,487,889$ \\
\hline Bank of America & 86 & $\$ 50,909,835,183$ \\
\hline Credit Suisse & 68 & $\$ 67,377,466,643$ \\
\hline Goldman Sachs & 56 & $\$ 64,312,858,906$ \\
\hline
\end{tabular}

Between 1986 and 2011, KKR-sponsored companies entered into at least 154 credit facilities in which JP Morgan was the lead or co-lead arranger, for a total of nearly $\$ 105$ billion. ${ }^{196}$ It is thus easy to understand why KKR's historic track record with JP Morgan affects the loan terms that KKR is able to obtain from JP Morgan in future deals, and provides strong incentives for KKR to ensure that JP Morgan is happy with the credit performance of KKR's portfolio companies. $^{197}$

195 DealScan Report, THOMSON REUTERS LPC, https://www.loanpricing. com/products/solutions-for-the-primary-market/loanconnectordealscan/

(datasets on file with author).

${ }^{196} I d$.

197 The literature on relationship banking is extensive, and focuses on the fact that repeat interactions between the same borrower and lender reduce information asymmetries between them, thereby allowing for better loan terms (or even for loans to be made in the first place). E.g., Sreedhar T. Bharath, Sandeep Dahiya, Anthony Saunders \& Anand Srinivasan, Lending Relationships and Loan Contract Terms, 24 REV. FIN. STUD. 1141, 1141-42 (2011). What is important to remember is that private equity firms are not themselves borrowers, and that (roughly speaking), we can think of each borrowing that a private equity firm negotiates as being for a totally different company. Thus, the traditional benefits for the lender from repeat lending (increasing familiarity with the company's operations, management, 


\section{Private Equity Firms’ Ability to Mitigate Agency Costs}

In order to act as gatekeepers, it is not sufficient that private equity firms have the incentive to mitigate agency costs; they must, of course, also have the ability to do so. Private equity firms satisfy this third gatekeeping requirement in that they are able to mitigate (though not eliminate) adverse selection and moral hazard problems with respect to their portfolio companies.

\section{Adverse Selection}

To keep things simple, imagine that a company approaches a single creditor and asks for a loan at the creditor's going rate for similar loans to companies in that industry and market. From the creditor's perspective, the problem of adverse selection is perhaps better described as three problems: (1) the statistical likelihood that the borrower is of "low" quality in the absence of any knowledge about its individual characteristics (which is determined by the percentage of low-quality companies among all those that approach the creditor to borrow funds); (2) the difficulty of determining the borrower's actual quality, assuming a perfectly trustworthy borrower (which is determined by factors such as the quality of the borrower's financial information, the ability to make accurate projections based on such information, and the ability to glean intangible features of the company, etc.); and (3) the possibility that the borrower might not be trustworthy, that is, that it might affirmatively misrepresent its quality to the creditor. Private equity firms have the ability to ameliorate each of these three facets of borrower adverse selection.

With respect to the first problem, private equity firms may increase the baseline probability that the borrower is of high quality through their skill in picking companies to acquire. Because they are in the business of making frequent acquisitions, it is at least plausible that they develop over time an expertise in identifying higher-quality companies. ${ }^{198}$ And if private equity firms are able to bring higher-

etc.) simply do not apply here. Instead, what makes the difference here is the gatekeeping role played by the private equity firm.

198 Just how plausible this advantage in picking companies is depends on how we define "higher-quality" or "better" companies. One possibility is that the company has been undervalued by the market (e.g., its growth rate 
quality companies to creditors in the first place, creditors will reward them with better debt terms. ${ }^{199}$ Thus, the private equity borrowing advantage may owe in part to private equity firms' reputations for picking better companies ex ante. If so, private equity firms perform not only the traditional, passive certification role of gatekeepers, but also an active selection or filtering role as well.

This role also explains how private equity firms can minimize the second problem for creditors: the difficulty of determining a given borrower's quality. In order to pick better companies, private equity firms must first accurately pinpoint a company's quality. Prior to making an acquisition, a private equity firm gleans significant information about the company through its extensive due diligence efforts (such as meeting repeatedly with management and engaging top-tier auditors and law firms to conduct due diligence). ${ }^{200}$ As the intended sole owner of the target, the private equity firm's stakes are higher than creditors' in determining the target's quality. Post-acquisition, the private equity firm controls the company and has direct access to all company information. ${ }^{201}$ Together these should translate into an ability to gauge the value of a company that is superior to one based solely on the information that borrowers provide to creditors. ${ }^{202}$

will be higher than what its share price currently reflects). The second is that the company has a superior ability to bear a heavy debt load (e.g., it will generate a large, predictable cash-flow, with minimal volatility). Private equity firms are far more likely to have an advantage over the rest of the market under the second definition, which incidentally is the measure of quality that creditors are far more concerned about. Because private equity acquisitions require a very high proportion of debt financing, private equity firms - unlike most acquirers - are almost exclusively focused on companies' ability to generate cash. Harry Cendrowski \& Adam A. Wadecki, Private Equity Governance Model, in PRIVATE EQUITY: HISTORY, Governance, AND Operations, 163, 170 (2d ed. 2012). This is why private equity valuations are always expressed as a multiple of EBITDA. It is less likely, however, that private equity firms could have an advantage in identifying undervalued companies, particularly in the large-cap area, where companies are typically auctioned off to several bidders in a highly competitive process. Bartlett, supra note 52, at 2016, 2018.

${ }^{199}$ Whitehead, supra note 15, at 665-66.

${ }^{200}$ Spindler, supra note 133, at 325.

${ }^{201}$ Masulis \& Thomas, supra note 71, at 223-24.

202 Of course, private equity's advantage in this regard should be inversely related to the availability of information about the companies at issue. The 
Finally, private equity firms are able to prevent the third type of adverse selection: actual misrepresentations to creditors. As sole shareholders of their portfolio companies, private equity firms have direct control of management and, for the reasons discussed above, will be able to recognize when management is misrepresenting information. $^{203}$

\section{Moral Hazard}

The ability to mitigate moral hazard in their portfolio companies is one of the key benefits of private equity firms' status as "insider" gatekeepers: they can limit misconduct by management because, unlike creditors, they have direct and continuous control over the borrower. ${ }^{204}$ As sole shareholders, they are able to prevent management from taking actions that harm the company's creditors, just as they are able to prevent management from misrepresenting the company's quality.

Private equity firms have an additional and highly valuable advantage over most borrowers in controlling moral hazard. If, despite best intentions, its portfolio company has defaulted - or is at risk of defaulting - on its debt, a private equity firm can put

more information about a company is available to the public, the less likely it is that private equity firms will find things that others have not. Thus, private equity's role in mitigating adverse selection may well be greater for smaller, private companies (in the middle-market or lower-middle market) than for large public companies.

${ }^{203}$ Davis, supra note 9, at 85.

${ }^{204}$ Masulis \& Thomas, supra note 71 , at 251 . However, that is not to say that creditors do not have any control over their borrowers. There is a wellestablished literature demonstrating that creditors impact their borrowers' corporate governance because they are able to exercise some measure of control over them. See generally Douglas G. Baird \& Robert K. Rasmussen, Private Debt and the Missing Lever of Corporate Governance, 154 U. PA. L. REV. 1209 (2005-2006) (criticizing traditional approaches to corporate governance that ignore the large and growing role of creditors); George G. Triantis \& Ronald J. Daniels, The Role of Debt in Interactive Corporate Governance, 83 CAL. L. REV. 1073 (1995) (offering an alternative theory of corporate governance that encompasses the interactions occurring between stakeholders and managers); Frederick Tung, Leverage in the Board Room: The Unsung Influence of Private Lenders in Corporate Governance, 57 UCLA L. REV. 115 (2009) (arguing that "private lender influence significantly constrains managerial discretion"). 
additional equity into the borrower to avoid or remedy the default. ${ }^{205}$ The latter option simply is not feasible for the shareholders of a public company, for example, yet it is a major benefit from a creditor's perspective in reducing moral hazard concerns.

In order to appreciate the value of private equity's role in mitigating the agency costs of debt, recall that private equity-backed companies are far more leveraged than their standalone company counterparts. ${ }^{206}$ The greater a company's leverage, the more severe its potential for both adverse selection and moral hazard. ${ }^{207}$ Adverse selection is exacerbated because higher-leveraged companies pay higher interest rates to compensate lenders for the additional risk of default. $^{208}$ Higher interest rates in turn attract lower-quality borrowers (who have less to lose than higher-quality borrowers). ${ }^{209}$ Moral hazard is exacerbated because shareholders' returns from taking actions that divert wealth from the company's creditors are increased when they have less of their own money at stake. ${ }^{210}$ All else being equal, therefore, a company with greater leverage imposes greater agency costs on lenders. Private equity firms' ability and incentives to mitigate these costs should therefore contribute to a material borrowing advantage in the market.

\section{Measuring Private Equity's Gatekeeping Performance}

The previous Part III and Appendix A demonstrate conceptually why private equity firms should be expected to act as gatekeepers in the debt markets. This Part IV examines what can (and cannot) be said about whether this is true in practice. Part A summarizes the limited, indirect empirical evidence currently available to support the claims of this Article and discusses the difficulties that preclude direct empirical support. Part B briefly advances three additional hypotheses - unrelated to the gatekeeper effect - for why private equity-owned companies might have a borrowing advantage over standalone companies.

\footnotetext{
${ }^{205}$ Hotchkiss et al., supra note 54, at 23-24.

${ }^{206}$ Davis, supra note 9, at 91.

${ }^{207}$ For a formal proof, see infra Appendix A, Section 1.

${ }^{208}$ See Cheffins \& Armour, supra note 30, at 45; Davis, supra note 9, at 91.

${ }^{209}$ Choi \& Triantis, supra note 118 , at 55-56.

${ }^{210}$ Smith \& Warner, supra note 134 , at 118-19.
} 


\section{A. Evidence}

Part II of this Article advanced two claims: first, driven by their reputational incentives, private equity firms act as gatekeepers in the debt markets; and second, a private equity-backed company should obtain more favorable debt terms than a non-sponsored company, all else being equal. In order to conclude that private equity firms act as gatekeepers, then, we would want evidence first, that private equity-sponsored companies get better debt terms, ceteris paribus, and, second, that reputation is the cause of this borrowing advantage. The available evidence (and lacunae) for each are discussed in turn below.

\section{Better Loan Terms for Private Equity?}

Practitioners and the financial press take it as a given that private equity firms obtain debt terms for their portfolio companies that others simply cannot match. ${ }^{211}$ Determining whether private equity-owned companies get better loan terms than comparable standalone companies would thus seem to be a relatively straightforward matter. In practice, however, direct empirical evidence is elusive because loans to private equity-backed and standalone companies cannot be sufficiently matched. There is too little overlap in the borrowing amounts ${ }^{212}$ and types ${ }^{213}$ of highly-

${ }^{211}$ See, e.g., Matthew Benjamin, Deal Mania, Shades of the '80s: The Leveraged Buyout Is Back in Vogue, U.S. News \& WoRlD ReP., Apr. 18, 2005, at 40; Andrew Ross Sorkin, The Money Binge: What Lies Behind All the Cash Driving the Record Run of Buyouts?, N.Y. TIMES, Apr. 4, 2007, at H1 (describing how the willingness of banks to "lend huge sums on friendly terms" has contributed to the increase in buyouts).

212 See generally Bartlett, supra note 52. Highly-leveraged public companies do of course exist, but they tend to cluster in very specific industries, such as airlines and cable companies, or are highly leveraged not by design, but as a result of deteriorating performance (so-called "fallen angels”). See Axelson, Jenkinson, Strömberg \& Weisbach, supra note 171, at 32 .

213 Private equity-backed companies are primarily financed with "bank debt." Public companies, for example, often opt for a different mix of debt financing types. See Kaplan \& Strömberg, supra note 8, at 141. The largest public companies will often issue commercial paper (for very short-term borrowing) and public bonds (for long-term borrowing), in lieu of bank debt. Cem Demiroglu \& Christopher James, 35 J. BANKING \& FIN. 775, 780 
leveraged private equity-backed companies and their less-leveraged standalone counterparts. ${ }^{214}$ Simply put, the assumptions underlying the "all else being equal" proviso are not satisfied. ${ }^{215}$

Paradoxically, however, the lack of data to support a direct empirical proof of the claim could be taken as evidence in favor of

(2011). What bank debt they do employ is used for the purpose of providing back-up liquidity, and is therefore generally in the form of an undrawn revolving credit facility, rather than the term loan favored by LBO companies. Amir Sufi, Bank Lines of Credit in Corporate Finance: An Empirical Analysis, 22 REV. FIN. STUD. 1057, 1067 (2009).

${ }^{214}$ One would expect the ideal test to be a comparison of the debt terms of a given company immediately prior to, and after, its acquisition by a private equity fund. Yet in virtually all instances, leveraged buyouts involve a major increase in the target company's leverage, which of course affects the terms of the debt independently of the company's ownership. See Bartlett, supra note 52, at 2014-16.

${ }^{215}$ The most obvious problematic assumption is that of identical leverage between private equity-backed companies and standalone companies, as discussed in the previous notes. A second assumption that proves problematic is that the private equity-owned company and the standalone company have the same amount of information available to creditors. Thus, a potential rebuttal to the claim would be that, at least for public companies, the void in monitoring is partially addressed by the greater availability of information about the borrower. Public companies are required to disclose material information publicly (and promptly), whereas private company information is less readily available. Healy \& Palepu, supra note 127 , at 411-12. Even assuming that the information required to be disclosed by public companies is especially useful for monitoring loan performance, the information gap between private equity-backed companies and public companies is decreasing, particularly with respect to the largest LBO portfolio companies. First, many of these companies issue not only bank debt, but also publicly-traded bonds, and therefore, subject themselves to the same reporting rules as public companies. Bartlett, supra note 88, at 15. Second, lenders generally impose financial and other reporting obligations in the credit agreement that are designed to approximate public company reporting, particularly with large borrowers. RICHARD WIGHT, WARREN COOKE \& Richard GRAY, THE LSTA's COMPLETE CREDIT AGREEMENT GUIDE 310-18 (2009). Third, the growth of syndication has been accompanied by the introduction of loan ratings by the major national rating agencies and detailed reporting on loan market in trade journals and the general financial media, all of which have narrowed the information gap between loans to private and public companies. STANDARD \& POOR's, A GUIDE TO THE LOAN MARKET 11 (2011), available at https://www. lcdcomps.com/d/pdf/LoanMarketguide.pdf. 
the claim. The paucity of highly-leveraged loans to standalone companies suggests that there is little appetite by lenders to provide so much leverage and on such favorable terms to such companiesthe market simply does not support it. $^{216}$ Consistent with the gatekeeper hypothesis, private equity firms enable companies to do something that - due to the excessive agency costs - they otherwise could not: borrow massive amounts of debt on highly favorable terms. ${ }^{217}$

Time-series data fare somewhat better than cross-sectional data in pointing at a private equity borrowing advantage. ${ }^{218}$ Over recent periods, for example, the evolution in debt terms seems to have been relatively more favorable to private equity-backed companies than to other companies. ${ }^{219}$ During the same 2004 to 2007 period during which private equity acquisitions surged, creditors' lending standards loosened dramatically; that is, debt terms improved for all borrowers. ${ }^{220}$ Yet the leveraged loan segment of the market, which is dominated by private equity-related borrowing, benefited disproportionately. ${ }^{221}$

\section{What's Reputation Got to Do with It?}

Even assuming a private equity borrowing advantage, there is still the matter of determining the extent to which it is due to

\footnotetext{
${ }^{216}$ Ivashina \& Kovner, supra note 13, at 2495 (acknowledging the lack of a true comparison set for loans issued by private equity-owned companies).

${ }^{217}$ Id. (explaining that "LBO firms' repeated interactions with banks create opportunities to reduce the costs associated with information asymmetries"). In fairness, however, this does not rule out the alternative explanation that standalone companies simply do not want to take on as much debt as private equity-owned companies. The debate over the optimal capital structure for companies is still largely unresolved. See Bartlett, supra note 52, at 1985-91.

${ }^{218}$ Demiroglu \& James, supra note 165, at 308-09, 315.

${ }^{219}$ E.g., Christenfeld \& Goodstein, supra note 163; Foley, supra note 163, at 12 .

${ }^{220}$ Demiroglu \& James, supra note 165, at 308 ("[S]ignificant declines, after 2002, in the proportion of traditional bank loans and the number and tightness of financial covenants associated with leveraged loans . . . suggest a decline in the intensity and importance of bank monitoring.").

${ }^{221} I d$. at 315 (explaining that "the decline in importance of covenants in loans to private equity firms only partly reflects an overall trend in credit market conditions").
} 
private equity firms' reputation for mitigating agency costs. ${ }^{222}$ Happily, recent empirical finance work demonstrates that private equity firm reputation positively affects the terms on which portfolio companies are able to borrow. ${ }^{223}$

First, Cem Demiroglu and Christopher James find that more established private equity firms obtain better financing terms for their portfolio companies than less well-established ones. ${ }^{224}$ Their findings hold under various measures of firm reputation (years in operation, assets under management, etc.). ${ }^{225}$ Because private equity firms are not liable for their portfolio companies' debts, the result that private equity sponsors' reputation impacts their portfolio companies' financing terms is surprising. The explanation offered here, of course, is that creditors reward private equity firms for their efforts at mitigating adverse selection and moral hazard in their portfolio companies.

Second, Victoria Ivashina and Anna Kovner find that the more a private equity firm interacts with the same lead arranger, the better its portfolio companies' debt terms will be. ${ }^{226}$ In our terms, private equity-backed companies obtain better debt terms when they are in repeated games with creditors than in end games. ${ }^{227}$ Granted, the effect on debt terms from such repeated interactions could also be due to private benefits that they afford the lead arranger (such as cross-selling opportunities), ${ }^{228}$ yet the authors find that the effect remains even after accounting for such benefits. ${ }^{229}$ Thus, the empirical results support the hypothesis that private equity firms' reputations with lenders provide an advantage in debt terms.

\footnotetext{
${ }^{222}$ A helpful test would be the comparison of management buyouts (MBOs) to leveraged buyouts (LBOs) because the former are akin to end-game financings, while the latter are repeated games. Thus, one would expect MBOs to obtain worse debt terms than LBOs. While anecdotal evidence suggests that this is indeed the case, the data on MBOs is insufficient for empirical testing of the claim.

${ }^{223}$ See generally Demiroglu \& James, supra note 165; Ivashina \& Kovner, supra note 13.

${ }^{224}$ Demiroglu \& James, supra note 165 , at 329.

${ }^{225} \mathrm{Id}$. at $316-17$.

${ }^{226}$ Ivashina \& Kovner, supra note 13, at 2495.

${ }^{227} \mathrm{Id}$. at $2480,2495$.

${ }^{228}$ See infra Part V.B.2.

${ }^{229}$ Ivashina \& Kovner, supra note 13, at 2487.
} 


\section{B. Additional Hypotheses for Private Equity Borrowing Advantage}

One of the difficulties in isolating and measuring the effect of a private equity firm's reputation on its portfolio companies' financing terms is that additional plausible hypotheses exist to explain why private equity-backed companies might have a borrowing advantage over standalone companies. In addition to the gatekeeper effect, the hypotheses include the following: (1) private equity-related loans are more liquid; (2) private equity firms get a volume discount from the major banks that arrange or underwrite their debt; and (3) private equity firms have a bargaining advantage in the debt markets. ${ }^{230}$

\section{Liquidity}

If we loosen the assumptions and no longer hold leverage constant, we find that private equity-owned companies borrow substantially more than comparable standalone companies. ${ }^{231}$ This affects private equity-owned borrowers' debt terms in two opposing ways. On the one hand, as discussed above, greater leverage gives rise to greater agency costs, and thus to greater credit risk. ${ }^{232}$ Yet on the other, the high leverage of private equity-related loans also provides one major benefit to creditors over less-leveraged loans, which is a lower liquidity risk. ${ }^{233}$ Contrary to all other U.S. capital markets (including the stock and bond markets), the riskiest assets are currently the most liquid in the corporate loan market. ${ }^{234}$ Specifically, "leveraged loans," 235 which are the type favored by

${ }^{230}$ These hypotheses will be discussed in greater detail in a companion piece to this Article.

${ }^{231}$ See generally Bartlett, supra note 52.

${ }^{232}$ Steven Drucker \& Manju Puri, On Loan Sales, Loan Contracting, and Lending Relationships, 22 REV. FIN. STUD. 2835, 2836 (2009).

${ }^{233}$ YAGO \& MCCARTHY, supra note 150, at 35-41. Liquidity can be thought of as the ease with which a loan can be sold to another lender.

${ }^{234}$ Drucker \& Puri, supra note 232, at 2835 (explaining that the secondary loan market is unusual in that trading "is dominated by leveraged, risky loans," unlike the public debt markets).

235 "Leveraged loan" is the pleonastic term used to describe loans to highlyleveraged borrowers. The technical definition of a leveraged loan is a matter of some debate, and is variously tied to loans with (1) interest rate margins 
private equity-owned companies, are more liquid than loans made to borrowers with low leverage. ${ }^{236}$

The basic impetus for this surprising phenomenon is that non-bank institutional lenders, which have rapidly taken the largest share of the market, are best suited to invest in a type of leveraged loan issued by private equity-firms (the eponymous "institutional" tranches), while the more traditional loans of investment grade borrowers are still funded almost exclusively by banks. ${ }^{237}$ With more lenders clamoring to fund private equity-related loans, the latter have become a highly liquid asset class, and are for this reason made on relatively better terms.

above a certain threshold or (2) credit ratings below a certain threshold. STANDARD \& POOR's, supra note 215, at 29.

${ }^{236}$ YAGO \& MCCARTHY, supra note 150, at 35-41.

${ }^{237}$ Id. at $18-22$. The more technical explanation is as follows. Secondary trading began with the originating banks, which, in response to new bank capital requirements, sought ways to diversify their loan holdings and began applying portfolio theory consistently beginning in the early 1990s. STANDARD \& POOR's, supra note 215, at 11. Changes to the mechanics of loan transfers followed rapidly, allowing for more efficient and rapid transfer and pricing of loans. YAGO \& MCCARTHY, supra note 150, at 2324. These changes included the founding of a trade association for the syndication and trading of loans (the LSTA), as well as the introduction of mark-to-market loan pricing, loan ratings by the national rating agencies, and standardized forms for the assignment of loans. Allison A. Taylor, The LSTA and Its Role in the Promotion of the Corporate Loan Assets Class, in THE HANDBOOK OF LOAN SYNDICATIONS AND TRADING 61-75 (Allison Taylor \& Alicia Sansone eds., 2006). Thereafter, the watershed moment was the SEC's promulgation of Rule 144A, which, among other things, allowed non-bank investors to begin trading syndicated loans. Thomas \& Wang, supra note 155 , at 304-05. New classes of institutional lenders, eventually including structured finance products such as CLOs, swarmed into the market, with very different goals and constraints than traditional banks. YAGO \& MCCARTHY, supra note 150, at 19-22. The end result was a vast new supply of lenders in the loan market, heavily tilted toward leveraged loans. $I d$. at 25 . While leveraged loans are heavily traded, it is still the case that, overall, most syndicated loans are not traded on the secondary market. Drucker \& Puri, supra note 232, at 2853 (acknowledging that only $20 \%$ of all syndicated loans are sold in the secondary market). 


\section{Volume Discount}

As repeat players in the debt and acquisition markets, private equity firms get the benefit of a form of volume discount from the large commercial and investment banks that syndicate and/or underwrite their debt. ${ }^{238}$ Such banks covet relationships with private equity firms, which provide them with both substantial transaction fee income from the debt financings ${ }^{239}$ and also cross-selling opportunities for more lucrative services, including securities underwriting and mergers and acquisitions ("M\&A") advisory services. ${ }^{240}$ In return for this additional income, the lead banks will provide private equity-owned companies with more favorable loan terms. $^{241}$

\section{Bargaining Advantage}

Through their repeated interactions with creditors, private equity firms become more sophisticated customers in the debt markets than standalone companies, and should therefore command more bargaining power than standalone companies in negotiating debt terms. ${ }^{242}$ Sophistication translates here into a twofold bargaining advantage of superior information and superior skill. First, private equity firms have an informational advantage over less frequent players in the debt markets as to what financing terms are currently the "market" terms. ${ }^{243}$ Because most financings are not made public, a standalone company will have far less knowledge of market terms than a private equity firm that is constantly in the debt markets for

\footnotetext{
${ }^{238}$ Ivashina \& Kovner, supra note 13, at 2462.

${ }^{239}$ Viral V. Acharya, Julian Franks \& Henri Servaes, Private Equity: Boom and Bust?, 19 J. APPLIED CORP. FIN. 44, 52 (2007).

${ }^{240}$ Ivashina \& Kovner, supra note 13, at 2462, 2464.

${ }^{241}$ Regarding the transaction fee income, it is worth noting that as the loan syndication market exploded, the fee component of a lender's return from a loan has become relatively more important because (1) the lead arranger might retain only a very small portion of the original loan and (2) the portion retained by the lead arranger can be more easily diversified now. Recent work finds that the lead arranger for LBO financing typically retains only $5-10 \%$ of the loan. $I d$. at 2469 .

${ }^{242}$ Axelson, Jenkinson, Strömberg \& Weisbach, supra note 171, at 2. Note that this assumes market power on both the borrower and lender sides of the market.

${ }^{243}$ Kaplan \& Strömberg, supra note 8, at 140-41.
} 
one of its portfolio companies. ${ }^{244}$ Private equity firms can and do use their market knowledge to negotiate for better debt terms. ${ }^{245}$ Second, private equity firms should be expected to develop greater skill in sourcing and negotiating large financings using resources such as their extensive bank contacts and their experience with everchanging finance structures and terms. Such skill manifests itself notably in the frequent innovations in debt terms that originate with private equity-related financings. ${ }^{246}$

Thus, gatekeeping by private equity firms need not be the sole explanation for their ability to obtain highly favorable loan terms for their portfolio companies; further work is needed to determine the relative importance of each explanation.

\section{Grading Private Equity's Gatekeeping Performance}

\section{A. Limitations on Private Equity's Gatekeeping}

While private equity firms can perform a valuable gatekeeping role in the debt markets, they are not a perfect cure for the conflicts between borrowers and lenders. Reputation mitigates, but does not eliminate, agency costs in a market. ${ }^{247}$ Thus, we would want to know not only how private equity firms are able to act as gatekeepers (as discussed in Part III), but also the particular conditions under which they are likely to be reliable or unreliable gatekeepers. This sub-part identifies the major limitations on private equity firms' gatekeeping performance. Per the framework

${ }^{244}$ See Cheffins \& Armour, supra note 30, at 59 (explaining “[p]rivate equity firms also rely heavily on confidential information to finalize bids before the competition is aware a target company is up for sale").

${ }^{245}$ Axelson, Jenkinson, Strömberg \& Weisbach, supra note 171, at 2.

${ }^{246}$ In the most recent wave of activity alone, private equity firms introduced or expanded several highly innovative (and borrower-favorable) loan terms and structures such as covenant-lite loans, equity cures, "yank-a-bank" provisions, PIK toggle loans, second-lien loans, amend-and-extend rights, partial refinancing rights, institutional tranches, accordion facilities, and so forth. Demiroglu \& James, supra note 165, at 307; STANDARD \& POOR's, supra note 215, at 25-27; Wight, supra note 28, at 218, 387.

${ }^{247}$ In the case of the prototypical gatekeeper, accounting firms, one need only consider the epic corporate accounting scandals from the early 2000s to be convinced that reputation is not a perfect panacea. See, e.g., John C. Coffee, Jr., Understanding Enron: "It's About the Gatekeepers, Stupid", 57 BUS. LAW. 1403, 1405 (2001-2002). 
introduced in Part II, they are divided into those that limit private equity firms' ability to act as gatekeepers and those that limit their incentive to act as gatekeepers.

At the outset, however, it is worth recalling that reputational harm is the sole incentive that prompts private equity firms to fulfill their gatekeeping role. ${ }^{248}$ Other gatekeepers may be compelled to act as such not only through market forces, but also by law. ${ }^{249}$ In contrast, private equity firms are pure market-based gatekeepers.

Nor do private equity firms typically assume any contractual liability to bond themselves to their gatekeeping role. ${ }^{250}$ Although private equity firms negotiate their portfolio companies' debt with creditors, the resulting contractual relationship is exclusively between each portfolio company and its creditors, with rare exceptions. ${ }^{251}$ Private equity's gatekeeping in the debt markets is solely driven by reputation, which is subject to well-recognized weaknesses in constraining company behavior. ${ }^{252}$

\section{Limitations on Private Equity's Gatekeeping Ability}

\section{a. Within-firm Agency Costs: Disloyal Agents}

The first set of limitations on private equity firms' gatekeeping are the agency costs within the gatekeeping firm itself. The interests of individual employees, partners, or even divisions of a firm (such as maximizing their compensation, prestige, etc.) may diverge from the interest of the firm as a whole in preserving its

${ }^{248}$ See Masulis \& Thomas, supra note 71 , at 239-40 (explaining why private equity firms act to prevent reputational harm).

${ }^{249}$ See Kraakman, supra note 97, at 54.

${ }^{250}$ Private equity funds resist guaranteeing their portfolio companies' debt largely for tax reasons. Much, if not most, of the private equity investor base is composed of tax-exempt organizations (such as pension funds or university endowments) and foreign institutions, both of which would face adverse tax consequences if the funds were to provide such guarantees. See 26 U.S.C. $\S \S 511,163(\mathrm{j})$ (2006); APPELBAUM \& BATT, supra note 3, at 13.

${ }^{251}$ Ivashina \& Kovner, supra note 13, at 2469 (explaining that private equity firms are not liable for their portfolio companies' debts other than to the extent of their initial equity investment).

${ }^{252}$ See generally Coffee, supra note 247. 
reputation. ${ }^{253}$ The largest U.S. accounting firms exemplify this tension. Typically, the interests of the firm would best be served by refusing to endorse unusually aggressive accounting by one of its clients because the loss in future firm income from the resulting reputational harm should outweigh the incremental income generated by that particular client. ${ }^{254}$ Yet the individual audit partner serving that client might be hard-pressed to say no to the client; his or her job may well depend on the firm's retaining that client. ${ }^{255}$

In the private equity context, a similar problem arises because individual private equity professionals' compensation is more heavily-weighted toward the deals that they help negotiate and close. One could imagine situations in which they were better off misleading creditors so as to get a deal done on otherwise unattainably good terms.

But this problem may be less severe with private equity firms than with traditional gatekeepers. The relatively small size of private equity firms ${ }^{256}$ compared to accounting firms, investment banks, and rating agencies, has three positive implications. Unlike the behemoths of the gatekeeping world, private equity firms should be able to monitor their professionals more closely and perhaps more readily convey to them the interests of the firm. ${ }^{257}$ Second, the pronounced intra-firm departmental conflicts of interest that exist in the larger gatekeeping organizations are unlikely to develop in smaller private equity firms. ${ }^{258}$ Finally, individual private equity professionals' compensation will be more closely tied to the fortunes of the firm as a whole than in a larger organization (since each will tend to have a greater share of the overall profits), thereby ensuring

${ }^{253}$ See id. at 1405 ("Despite the clear logic of the gatekeeper rationale, experience over the 1990s suggests that professional gatekeepers do acquiesce in managerial fraud, even though the apparent reputational losses seem to dwarf the gains to be made from the individual client.").

${ }^{254}$ Coffee, supra note 99 , at $310-11$.

${ }^{255} I d$. at 316 (describing that analysts and auditors are "'reputational intermediaries,' whose desire to be perceived as credible and objective may often be subordinated to their desire to retain and please" clients).

${ }^{256}$ Jensen, supra note 73, at 69-70.

${ }^{257}$ Masulis \& Thomas, supra note 71, at 224.

${ }^{258}$ A classic example is the case of securities analysts being pressured to give misleading company reviews by the investment bankers within the same firm. Coffee, supra note 99, at 315-18. 
that their incentives are more closely aligned. ${ }^{259}$

\section{b. Difficulties in Obtaining Company Information}

Private equity's role in minimizing adverse selection depends on its ability to obtain company information that is not readily available to creditors. ${ }^{260}$ Ironically, when private equity is experiencing a peak of activity, its information advantage is at its weakest. During a hot acquisition market, sellers have greater bargaining power relative to acquirers. ${ }^{261}$ This allows sellers to substantially shorten the target's auction timeline, to provide very limited information about the target to bidders, and to limit bidders' opportunity to perform their own due diligence (such as by meeting with the company's management). ${ }^{262}$

Under such conditions, a private equity firm may be less successful at mitigating adverse selection for two reasons. First, it will have gathered less information about the target company than it would have under normal market conditions, and thus may not be able to reliably certify its quality to creditors. Second, a hot acquisition market is a more competitive one, in which private equity firms are less likely to find undervalued companies; anything that they identify as a diamond in the rough is likely to be a fake.

\section{Limitations on Private Equity's Gatekeeping Incentives}

\section{a. Market Bubbles}

During a market bubble, the value of a gatekeeper's reputational capital declines. ${ }^{263}$ Investors experience so much pressure to invest that they disregard or give less weight to

${ }^{259}$ Kaplan \& Strömberg, supra note 8, at 131; Masulis \& Thomas, supra note 71, at 227-28.

${ }^{260}$ Ivashina \& Kovner, supra note 13 , at 2466.

${ }^{261}$ See Ivashina \& Sun, supra note 135, at 506-07.

${ }^{262}$ See Lisa Read Blanco \& Jaron Brown, How to Auction Your Company to a Private Equity Fund, EXECUTIVE COUnsel, July/Aug. 2007, available at http://www.kslaw.com/Library/publication/ExecCounsel_BlancoBrown. pdf.

${ }^{263}$ Coffee, supra note 247, at 1412; Coffee, supra note 99, at 310. 
gatekeepers' pronouncements. $^{264}$ The result is increased permissiveness by gatekeepers because the cost of being permissive (reputational harm) has declined relative to the benefits. ${ }^{265}$

By most accounts, a bubble did indeed occur in the debt markets during the 2005 to 2007 lead-up to the global financial crisis. $^{266}$ The market experienced a glut of capital $^{267}$ from institutional investors chasing high returns and engaged in herding behavior, ${ }^{268}$ resulting in a surge in liquidity that coincided with the most recent private equity boom. Yet while many feared a devastating post-bubble wave of defaults by the highly-leveraged private equity-backed companies, as of 2013, we have yet to witness it. ${ }^{269}$ Nonetheless, it may still be the case that creditors were not adequately compensated for the level of risk that they assumed during the go-go-go period. $^{270}$

\section{b. Rational Firm Decisions to Sacrifice Reputation}

Even assuming that all of a gatekeeper's agents are perfectly loyal, there are circumstances in which the gatekeeper firm itself might still permit corporate misbehavior. A gatekeeper may rationally decide to deplete its reputational capital if doing so would maximize its expected profits. ${ }^{271}$ For example, an exogenous factor

${ }^{264}$ See Coffee, supra note 99, at 329.

${ }^{265} \mathrm{Id}$. at 324.

${ }^{266}$ Acharya et al., supra note 239 , at 45.

267 The pre-crisis glut of capital in the debt markets has been variously attributed to Asian governmental surpluses, excess oil profits, and a surge in pension, foundation, and private wealth. Id. (citing Edward I. Altman, Global Debt Markets in 2007: New Paradigm or the Great Credit Bubble?, 19 J. APPLIED CORP. FIN. 17, 17 (2007)).

${ }^{268}$ E.g., Ivashina \& Sun, supra note 135, at 502 (concluding that, contrary to the predictions of an efficient market, the demand curve for syndicated corporate loans is downward sloping, such that exogenous shifts in the supply of capital to the market affect loan valuations).

${ }^{269}$ Christenfeld \& Goodstein, supra note 163 (stating that "default rates are generally at their lowest in many years"); Kaplan \& Strömberg, supra note 8 , at 129 (finding a lower default rate for their sample of private equityowned companies than for all U.S. corporate bond issuers from 19802002).

${ }^{270}$ Shivdasani \& Wang, supra note 152, at 1324.

${ }^{271}$ Partnoy, supra note 191 , at 367. 
may change the calculus for the gatekeeping firm in such a way that permissiveness becomes the optimal strategy, notwithstanding the long-term harm to the firm's reputation. In the private equity context, one can derive plausible scenarios to that effect without much difficulty.

First, when private equity firms recognize that they are at the end of a cycle of activity - for instance, because credit markets are drying up or target companies are overvalued - they might conclude that the benefit from misrepresentation or misconduct toward creditors outweighs the harm to their reputation, since they cannot be certain that they will survive until the next cycle of activity.

Second, a private equity firm that is in the process of fundraising for its next fund may be particularly eager to quickly close an acquisition with its existing fund, rationally sacrificing some of its long-term reputation in exchange for a short-term boost in publicity. $^{272}$

Finally, we have the obvious point that private equity firms with less well-established reputations are more likely to be permissive. Upstart private equity firms have less reputational capital with creditors (and thus less to lose from putting it at risk) and more incentives to "bet the farm" in order to produce higher returns in the short term. ${ }^{273}$

272 Rashida K. La Lande, Gibson, Dunn \& Crutcher LlP, Private EQUity STRATEgIES FOR EXITING A LEVERAGEd BUyOUT 2 (2011), available at http://www.gibsondunn.com/publications/Documents/ LaLande-PrivateEquityStrategiesforExitingaLeveragedBuyout.pdf. For a different account of the relationship between the timeline of a private equity fund and the likely outcome for creditors of its portfolio companies, see Hotchkiss et al., supra note 54, at 20 (arguing that a given portfolio company is less likely to default on its debt if the private equity fund was raised recently, because the fund has more undrawn capital and thus more ability to contribute additional equity to prevent a default).

${ }^{273}$ Meuleman et al., supra note 167, at 625 (arguing that "[b]ecause young PE companies have more incentives to prove themselves so as to establish a reputation, they are likely to take on more risky investment projects with higher potential outcomes"). Here again, the finding that more reputable private equity firms get better debt terms is particularly helpful. Demiroglu \& James, supra note 165 , at 306. 


\section{c. Conflicts of Interest}

Conflicts of interest are another well-recognized source of gatekeeping lapses. ${ }^{274}$ In the private equity sphere, a serious conflict of interest arises when a private equity firm is owned by a bank. ${ }^{275} \mathrm{In}$ such cases, the bank can both acquire a company through the private equity fund and arrange and/or underwrite all of the company's debt. $^{276}$ Such a combination of roles has negative systemic effects ${ }^{277}$ and, for our purposes, results in greater adverse selection and moral hazard problems toward the ultimate creditors in the syndicate. However, this conflict of interest should be precluded going forward by the Volcker Rule in the Dodd-Frank Wall Street Reform and Consumer Protection Act ("Dodd-Frank Act"), which drastically limits the ability of U.S. banks to invest in or form private equity funds. ${ }^{278}$

To conclude this sub-part, private equity firms face important limitations on their gatekeeping abilities and incentives, though they may fare better in this regard than larger, more traditional gatekeepers. The lessons for private equity firms and creditors are two-fold. First, private equity firms must pay close attention to their compensation practices to ensure that individual professionals are not incentivized to act against the firm's interests by cheating creditors. Second, private equity firms will be less reliable gatekeepers during bubbles in both the M\&A and debt markets, though this warning is by definition unlikely to be heeded by investors and creditors at the time.

What can be said at this stage is that private equity firms should be expected to improve their portfolio companies' behavior towards creditors to some degree, which will vary by firm and over

${ }^{274}$ An oft-cited example is the fact that the debt rating agencies are paid by the companies that they are supposed to rate. E.g., John Patrick Hunt, Credit Rating Agencies and the "Worldwide Credit Crisis": The Limits of Reputation, the Insufficiency of Reform, and a Proposal for Improvement, 2009 Colum. Bus. L. REV. 109, 152 (2009).

${ }^{275}$ See Lily Fang, Victoria Ivashina \& Josh Lerner, Combining Banking with Private Equity Investing, 26 REV. FIN. STUD. 2139, 2140 (2009).

${ }^{276} I d$.

${ }^{277} \mathrm{Id}$

${ }^{278}$ See Dodd-Frank Wall Street Reform and Consumer Protection Act, Pub. L. No. 111-203, § 619, 124 Stat. 1376 (2010) (codified in scattered sections of the U.S. Code) [hereinafter Dodd-Frank Act]. 
time. The next sub-part briefly examines how private equity firms stack up against the other major gatekeepers in the debt markets: the credit rating agencies.

\section{B. A Word on Credit Rating Agencies}

The credit rating agencies are natural candidates for gatekeeping in the debt markets. Their sole stated function is to gauge the quality of debt instruments from the perspective of creditors. ${ }^{279}$ The two largest credit rating agencies, Moody's and Standard \& Poor's, each have over a century of experience rating debt products. ${ }^{280}$ Presumably then, they have developed substantial expertise in assessing a borrower's credit risk, ${ }^{281}$ and the reliability of their ratings is assured by their long-standing reputations.

In practice, however, the rating agencies suffer from perennial problems that drastically limit the role of reputational capital in explaining their performance. ${ }^{282}$ Key criticisms include that rating agencies are highly concentrated, massive organizations ${ }^{283}$ that are subject to severe conflicts of interest. ${ }^{284}$ Further, rating agencies may not actually provide investors with new information on borrowers' creditworthiness, but instead merely react to information

${ }^{279}$ Hunt, supra note 274 , at 114-15; see generally STANDARD \& POOR's, supra note 215.

280 Ratings Definitions, MoODY's, https://www.moodys.com/ratingsprocess/Ratings-Definitions/002002 (last visited Nov. 22, 2013); About Us, STANDARD \& POOR's, http://www.standardandpoors.com/about-sp/main/ en/us (last visited Nov. 22, 2013).

${ }^{281}$ For a broad description of the proprietary methodology by which Standard \& Poor's rates corporate loans, see Standard \& Poor's, A Guide to the Loan Market, supra note 215, at 32-35.

${ }^{282}$ Hunt, supra note 274, at 113. But see Claire A. Hill, Regulating the Rating Agencies, 82 WASH. U. L.Q. 43, 59-62 (2004) (describing how Moody's and Standard \& Poor's hold $80 \%$ of the market share and are generally relied upon by firms); Steven L. Schwarcz, Private Ordering of Public Markets: The Rating Agency Paradox, 2002 U. ILL. L. REV. 1, 26 (2002) ("Rating agencies are already motivated to provide accurate and efficient ratings because their profitability is directly tied to reputation. Historical data confirm that the reputational motivation is sufficient.")

${ }^{283}$ Frank Partnoy, The Siskel and Ebert of Financial Markets?: Two Thumbs Down for the Credit Rating Agencies, 77 WASH. U. L.Q. 619, 64849 (1999).

${ }^{284}$ Hunt, supra note 274, at 113. 
that is already available to the market. $^{285}$ Finally, and most damningly, though rating agencies purport to provide credit ratings, the bulk of their profits derive instead from selling regulatory entitlements. ${ }^{286}$ U.S. financial regulations are increasingly tied to credit ratings, leading market participants to push for higher ratings for credit products regardless of their underlying credit risk. ${ }^{287}$ In this story, companies, investors, and investment managers are all complicit in the rating agencies' practice of assigning artificially high ratings; the market expects and encourages the rating agencies to perform their gatekeeping role poorly. ${ }^{288}$ In hindsight, all of these problems figured prominently in the disgraceful performance of the rating agencies leading up to the global financial crisis. ${ }^{289}$

It is also worth noting that the credit rating agencies are relative novices when it comes to corporate loans (which represent the largest share of debt issued by private equity-owned companies), as opposed to public bonds, having only begun rating the former in $1996 .{ }^{290}$ The demand for corporate loan ratings arose only recently, when the loan market began to look more like the bond market in

285 Partnoy, supra note 283, at 621.

${ }^{286}$ Id. at 623-24; Frank Partnoy, How and Why Credit Rating Agencies Are Not Like Other Gatekeepers, in FINANCIAL GATEKEEPERS: CAN THEY Protect InVEStors? 59, 64 (Yasuyuki Fuchita \& Robert E. Litan eds., 2006).

${ }^{287}$ Partnoy, supra note 286, at 75-76.

${ }^{288}$ See id. As an example, imagine that you are the investment manager for a large pension fund. For prudential reasons, SEC regulations require a minimum percentage of the fund's assets to be invested in cash or AAArated investments. Like any good investor, you know that low-risk assets (such as AAA-rated ones are intended to be) provide low returns. Since your compensation is based on achieving high returns for the pension fund and doing so demands greater risk, you will be happiest under a regime in which high-risk investments are falsely rated AAA.

${ }^{289}$ See generally Complaint, United States v. McGraw-Hill Companies, No. CV13-00779 (C.D.C.A. filed Feb. 4, 2013), available at http:// www.justice.gov/iso/opa/resources/849201325104924250796.PDF; Press Release, U.S. Dep't of Justice, Department of Justice Sues Standard \& Poor's for Fraud in Rating Mortgage-Backed Securities in the Years Leading up to the Financial Crisis (Feb. 5, 2013), available at http://www.justice.gov/opa/pr/2013/February/13-ag-156.html [hereinafter DOJ Press Release] (alleging that Standard \& Poor's “issued inflated ratings that misrepresented the securities' true risks").

${ }^{290}$ Page \& Swaffield, supra note 16 , at 33. 
terms of liquidity and creditor dispersion. ${ }^{291}$

However, the spectacular pre-crisis failures of the rating agencies were not related to their ratings of corporate bonds or syndicated loans. ${ }^{292}$ Rather, the culprit was the ratings of the structured finance products tied to other assets - including bonds and loans. ${ }^{293}$ It is during this boom period that the practice of securitization exploded. ${ }^{294}$ In order to provide investors with cheap diversification and access to new asset classes, while keeping risky assets off their own books, financial institutions pooled cashproducing assets (such as mortgages, credit card receivables, bonds, and syndicated loans) and sold investors rights to them. ${ }^{295}$ The rating agencies were called in to rate the securities issued by these securitization vehicles, and the market quickly witnessed the oddity of AAA ratings for securities tied to junk-rated assets. ${ }^{296}$ Coffee's "market bubble story" 297 seems a particularly fitting explanation: caught in the illusion of ever-increasing asset prices (in particular, housing prices), investors ceased doing their own due diligence, and the rating agencies succumbed to the allure of the seemingly endless stream of fees generated by the securitization machine. ${ }^{298}$

While there is widespread agreement about the rating agencies' failures in the mortgage securitization realm, the jury is still out on their performance in rating operating companies' debt and the securitization vehicles (such as CLOs and CBOs) that invest in them. ${ }^{299}$ Even if credit rating agencies accurately rate the

${ }^{291}$ Hill, supra note 282, at 53-54.

${ }^{292}$ DOJ Press Release, supra note 289.

${ }^{293} \mathrm{Id}$.

294 Kurt Eggert, The Great Collapse: How Securitization Caused the Subprime Meltdown, 41 CoNN. L. REV. 1257, 1266-67 (2009).

${ }^{295}$ Id. at 1265; Howell E. Jackson, Loan-Level Disclosure in Securitization Transactions: A Problem with Three Dimensions, in MOVIng ForWARD: The Future of CONSUMER CREDIT AND MORTGage FinANCE 189 (Nicholas P. Retsinas \& Eric S. Belsky eds., Brookings Institution Press 2011).

${ }^{296}$ Eggert, supra note 294, at 1266-67.

${ }^{297}$ Coffee, supra note 99, at 323.

298 Eggert, supra note 294, at 1298-1301. For the post-crisis regulatory fallout for the rating agencies, see Aline Darbellay \& Frank Partnoy, Credit Rating Agencies Under the Dodd-Frank Act, 30 No. 12 BANKING \& FIN. SERVICES POL'Y REP. 1, 3 (Dec. 2011).

${ }^{299}$ For the relevant differences between subprime mortgages and corporate loans, see Whitehead, supra note 15 , at 646-50. 
underlying company debt, if they are overly permissive in rating the securitization vehicles that invest in them, which now represent over $60 \%$ of the leveraged loan market, ${ }^{300}$ it will result in over-lending to borrowers or in lending on overly permissive terms.

With respect to the specific goal of minimizing borrower agency costs, it would seem that the credit rating agencies can perform, at best, only part of the task. Even assuming that they provide perfectly accurate ratings, this amounts only to an ex ante certification role, rather than an ex post monitoring role. The credit rating agencies' key performance is completed upfront, in rating the debt at the time it is issued. ${ }^{301}$ While the rating agencies may downgrade a particular debt instrument after it has been issued, usually this will only be in response to information that is already public and therefore already reflected in its price, if it is traded. ${ }^{302}$ More importantly, a downgrade is unlikely to effectively prevent corporate misbehavior ex ante to the same extent that private equity ownership would, all else being equal. It is true that issuers can be "punished" by a downgrade (say, if it further reduces the trading price of their debt), but two observations are in order. ${ }^{303}$ First, downgrades are rare, reserved for borrowers with widely known problems. ${ }^{304}$ Second, downgrades can only deter bad borrower behavior ex ante if the borrower has strong reputational stakes in the debt markets. And, as we have seen, this is less likely to be the case with most borrowers than it is with private equity-owned borrowers.

Another way to see this is to consider that the rating agencies suffer no reputational harm themselves when they downgrade a borrower; the borrower's misconduct after the loan has been issued does not reflect poorly on the rating agencies, but only on the borrower. ${ }^{305}$ In contrast, private equity firms are held responsible for misbehavior by their portfolio companies, and suffer reputational harm as a result. ${ }^{306}$ To conclude, even assuming that rating agencies are helpful in mitigating borrower adverse selection, by certifying

\footnotetext{
${ }^{300}$ Bobrow et al., supra note 152 , at 166.

${ }^{301}$ See Hill, supra note 282, at 48-50.

302 Partnoy, supra note 283, at 661 .

${ }^{303}$ See Hill, supra note 282, at 68 ("The very fact of a downgrade has an effect; even if no information about the present financial situation is being conveyed, investors will react.").

${ }^{304} \mathrm{Id}$. at $65-67$.

${ }^{305}$ See id. at 68-70.

${ }^{306}$ Masulis \& Thomas, supra note 71, at 239.
} 
borrowers' quality ex ante, it is unclear whether rating agencies have any significant effect in mitigating borrower moral hazard.

These existing (and widening) gaps in gatekeeping coverage in the debt markets create an opportunity for private equity firms to play a highly valuable role. ${ }^{307}$ The last piece of the puzzle is to determine how regulators should respond.

\section{Regulatory Implications}

Demonstrating that private equity adds value through gatekeeping does not answer the question of whether private equity increases social welfare overall: private equity has well-known costs associated with it, and the task of weighing these against its benefits is far from complete. Yet, it does disprove the common claim that regulators could costlessly stamp out or curtail private equity.

Separately, the gatekeeper theory of private equity challenges the wisdom of the recent regulatory push to make private equity firms more accountable to their investors. Under the Dodd-Frank Act, private equity firms are now, with very limited exceptions, required to register as investment advisers under the Investment Advisers Act of $1940 .^{308}$ This change represents a fundamental shift in the regulation and nature of private equity. The word "private" in private equity is no accident: private equity firms have always been notoriously loath to share detailed information about their investments and returns with even their own investors, and have jealously guarded their status as largely unregulated players. ${ }^{309}$

${ }^{307}$ Frank Partnoy, among others, has proposed relying on credit default swap ("CDS") spreads as an alternative to the credit rating agencies. Mark J. Flannery, Joel F. Houston \& Frank Partnoy, Credit Default Swap Spreads As Viable Substitutes for Credit Ratings, 158 U. PA. L. ReV. 2085, 2085 (2010). Because the return on a CDS is determined by the probability of a given company defaulting on its debt, its price should reflect the market's view of the company's creditworthiness at any given time. Id. at 2088. Yet CDSs do not exist or are not heavily traded for most of the companies that private equity funds might acquire, particularly the smaller, private companies.

${ }^{308}$ Dodd-Frank Act, supra note 278 , at $\S \S 401-416$. The only private equity firms exempt from the registration requirement are certain foreign managers, small fund managers, and managers falling within the narrow category of "venture capital fund" advisers. Id. $\S \S 403,407$.

309 See Mohsen Manesh, Legal Asymmetry and the End of Corporate Law, 34 DEL. J. CORP. L. 465, 468 (2009). 
As registered investment advisers, private equity firms will join the ranks of advisers such as mutual fund managers that are well accustomed to tight regulation and public scrutiny. In addition to putting private equity squarely on the securities regulators' radar screen, this change is designed to make private equity firms more accountable to their own investors. ${ }^{310}$ It imposes additional public disclosure obligations and compliance requirements on private equity firms, and subjects them to anti-fraud provisions, above and beyond what investors in their funds may have contracted for. ${ }^{311}$ Most significantly, registered investment advisers have non-waivable fiduciary duties toward their investors ${ }^{312}$ - duties which private equity firms have heretofore deliberately avoided. ${ }^{313}$ Notably, these changes did not come about at the behest of private equity investors.

Ironically, the result of making private equity firms more accountable to their investors may well be lower returns for such investors (in addition to increased borrowing costs for portfolio companies), precisely because doing so hinders private equity firms' ability to act as gatekeepers. To successfully perform their gatekeeping function, private equity firms must have the leeway to forego short-term profit opportunities at creditors' expense for the sake of maximizing long-term profit by maintaining a good reputation with creditors. ${ }^{314}$ This privileging of long-term reputation

\footnotetext{
${ }^{310}$ Press Release, U.S. Sec. \& Exch. Comm'n, SEC Adopts Dodd-Frank Act Amendments to Investment Advisers Act (June 22, 2011), available at http://www.sec.gov/news/press/2011/2011-133.htm.

${ }^{311}$ See Investment Advisers Act of 1940, 15 U.S.C. $\S \S 80 b-1$ to -21 (2006).

${ }^{312}$ SEC v. Capital Gains Research Bureau, 375 U.S. 180, 194 (1963).

${ }^{313}$ In the past, limited partnership agreements for private equity funds often required investors (the limited partners) to waive the fiduciary duties of the private equity firm (the general partner). William A. Birdthistle \& M. Todd Henderson, One Hat Too Many? Investment Desegregation in Private Equity, 76 U. CHI. L. REV. 45, 51-53 (2009). In Delaware, the jurisdiction of choice for U.S. private equity limited partnerships, such as waiver is expressly permitted by statute. DEL. CODE ANN. tit. 6, § 17-1101(d) (providing that the general partner's fiduciary duties "may be expanded or restricted or eliminated by provisions in the partnership agreement," with the exception of the contract-based duty of good faith and fair dealing). For a history of this provision and its impact, see Birdthistle \& Henderson, supra.

${ }^{314}$ In other words, a key reason why private equity investors grant wide latitude to private equity firms in their fund agreements is that this structure maximizes long-term returns to investors. Axelson, Strömberg \& Weisbach,
} 
maximizes returns for investors in private equity funds as a whole and over time. ${ }^{315}$ The difficulty is that individual investors in private equity funds do not have the same incentive as the private equity firm itself to preserve the firm's long-term reputation, primarily because private equity funds have limited lifecycles. ${ }^{316}$

Take a given investor in a given private equity fund of a given private equity firm, and assume that the fund will complete only six acquisitions during its ten-year life span. Once the fund has invested all of its pooled cash, the private equity firm will raise a successor fund, and so on ad infinitum. (In addition, the private equity firm manages several active funds at any given time, each with a different investment focus.) Assume that the fund in question is on the verge of making its final acquisition. At this point, unless it has committed to invest in the successor fund, our investor will want the private equity firm to defect from its long-term, optimal strategy of behaving well towards creditors. The investor will want the private equity firm to maximize short-term profits on the fund's final deal by extracting as much wealth as possible from creditors, because it will bear none of the future harm from the private equity firms' loss of reputation. ${ }^{317}$ Having benefited from the private equity firm's reputational capital up until that point (through cheaper debt for the fund's acquisitions), the investor will now want the firm to spend all of that capital on the final deal. Thus, if the private equity firm, as a registered investment adviser, has a fiduciary obligation to maximize profits for its investors in each fund and is required to disclose all pertinent return calculations to investors, it may well be forced into maximizing short-term profits at the expense of its longterm reputation and long-term profits. ${ }^{318}$

supra note 173, at 1549 (justifying the particular structure of private equity funds as maximizing returns to limited partners (investors)). In essence, the fund agreement is a self-binding mechanism for investors, preventing individual opportunistic behavior that would harm the group.

${ }^{315} I d$.

${ }^{316}$ Id. at 1574 .

317 The private equity investor's incentives are thus very different from those of a public equity investor. Because public companies have infinite lives and investment periods and their shares are liquid, the public company shareholder should generally want to maximize the long-term value of the company because it will determine today's share price.

318 Of course, what fiduciary duties actually require in this example is unclear. For an overview of the problem of fiduciary duty indeterminacy in 
Thus, making private equity firms more accountable to their investors may well impede private equity firms' gatekeeping function, to the detriment of private equity investors as a whole. ${ }^{319}$ This, in turn, will undercut the gatekeeping benefits of a lower cost of capital for portfolio companies and lower agency costs. In the absence of material benefits to investors from having private equity firms register as investment advisers, this policy choice seems unwise. $^{320}$

\section{Conclusion}

Private equity firms have evolved from "Barbarians at the Gate" into keepers of the gate. By using their reputations to bridge the information gap between companies and lenders, private equity firms afford companies access to unprecedented levels of debt financing, and on highly favorable terms. This novel conception of private equity firms as gatekeepers suggests that their value lies at least as much in their ability to broker cheap debt as in their muchtouted expertise with "turnarounds" and corporate governance. And private equity firms will continue to be handsomely rewarded for their gatekeeping services: with today's increasingly complex and dispersed corporate lending structures, reputable private equity firms fill a gaping void left by a decline in lender monitoring and the

corporate law, see Seth Davis, The False Promise of Fiduciary Government, 89 Notre DAME L. REV. (forthcoming 2014).

319 The same is true of the very recent phenomenon of private equity firms themselves "going public." In an irony of both nomenclature and mission, some of the very largest private equity firms in the world have recently issued shares to the general public. Manesh, supra note 309, at 466-70 (describing prominent examples of private equity firms going public). Though much has been made of the repercussions for corporate governance (of both the private equity firm and its portfolio companies), the repercussions for private equity's borrowing advantage have been entirely overlooked. By tethering private equity firms to short-term stock price movements, public shareholders may lose the long-term value of private equity firms' ability to obtain favorable financing for portfolio companies.

${ }^{320}$ In contrast, the gatekeeper theory of private equity does not entail any a priori objections to other recent policy prescriptions affecting private equity, including (1) the proposed elimination of the favorable tax treatment for private equity professionals and (2) the Volcker Rule prohibition on banks investing in or sponsoring private equity funds. See supra notes 66, 283-84 and accompanying text. 
failure of traditional debt-market gatekeepers. Demonstrating that private equity creates value through gatekeeping dispels the persistent myth of private equity as a mere wealth transfer. That should change both our understanding of private equity and our approach to regulating it.

\section{Appendix A: Repeated-Game Model of Private Equity Borrowing}

The model below demonstrates that private equity firms' reputational stakes in the debt markets incentivize them to mitigate agency costs in their portfolio companies, resulting in lower costs of debt capital for private equity-owned companies as a whole.

Section 1 models the credit decision in an end-game between a borrowing company and its lenders. It demonstrates that lenders will demand higher interest rates to lend to companies with highly leveraged capital structures (including private equity portfolio companies), due to their increased agency costs. ${ }^{321}$ The initial setup of the debt agency cost problem in Section 1 is a modification of the basic credit-rationing model found in Tirole (2006). ${ }^{322}$

Section 2 extends the framework to show that a private equity firm's concern for its reputation in the debt markets- that is, for its future payoffs in repeated iterations of the lending game - can mitigate the debt agency problem. Specifically, it models the credit decision in an indefinitely repeated game between a private equity firm, negotiating debt financing for one of its portfolio companies, and lenders. The model demonstrates that under plausible conditions, private equity firms are incentivized to behave well toward lenders (that is, to limit moral hazard in the borrowing company) in every round of the game because lenders will reward such behavior with lower interest rates.

\section{Section 1. End Game Between Borrower and Lender}

Take a company with initial assets $A$, where $A$ is the owner's equity stake in the company or net worth. The company wishes to make an investment $I$. The company can invest in either a "good" project $G$ or a "bad" project $B$. There are only two possible outcomes for each project, "success" or "failure." The bad project $B$ has a

${ }^{321}$ Of the two debt agency costs, moral hazard and adverse selection, this model covers only the former for simplicity.

${ }^{322}$ See TIROLE, supra note 124 , at 114. 
higher return in the event of success $\left(R^{B}>R^{G}\right)$, but a lower (zero) return in the event of failure $\left(F^{G}>F^{B}=0\right)$. The probability of success for the bad and good projects are $p^{B}$ and $p^{G}$, respectively, where $p^{G}>$ $p^{B}$. While each project has a positive net value (i.e., $I$ is less than the expected return on the project), project $B$ is worse than project $G$ from the point of view of a risk-neutral investor, in the sense that the expected return on $B$ is less than the expected return on $G$. That is:

$I<p^{B} R B \quad<\left(p^{G} R^{G}+\left(1-p^{G}\right) F^{G}\right)$

In order to make the investment, the company borrows ( $I-$ $A$ ) at an interest rate $r$. For simplicity, we ignore time by assuming that investment and repayment happen almost simultaneously, such that $r$ reflects only the risk premium.

The company will prefer to invest in project $G$ so long as the expected profit to the company from $G$ exceeds the expected profit to the company from $B$ :

$p^{G}\left(R^{G}-(1+r)(I-A)\right)$

$+\left(1-p^{G}\right) \operatorname{Max}\left[F^{G}-(1+r)(I-A), 0\right]$

$>p^{B}\left(R^{B}-(1+r)(I-A)\right)$

We assume $F^{G}<(1+r)(I-A)$; that is, the good project is not a sure thing from the lenders' perspective. Thus, the company chooses the good project so long as:

$$
\begin{aligned}
& p^{G}\left(R^{G}-(1+r)(I-A)\right)>p^{B}\left(R^{B}-(1+r)(I-A)\right) \\
& A>I-\frac{p^{G} R^{G}-p^{B} R^{B}}{\left(p^{G}-p^{B}\right)(1+r)}
\end{aligned}
$$

Thus, companies having assets/equity exceeding this threshold will invest in the good project $G$, while companies with insufficient equity will invest in the bad project $B$-they will succumb to moral hazard. Stated differently, the agency costs of debt increase with the company's leverage.

In this market, lenders will therefore lend at two different rates of interest: one for companies with enough equity (enough "skin in the game") - that is, those satisfying equation (1) - and one for companies with low equity/high leverage. This is because the risk premium for lenders is different for the high-equity (low-leverage) 
borrowers, who will invest in the good project $G$, and the low-equity (high-leverage) borrowers, who will invest in the bad project $B$. If the lenders are perfectly competitive and risk-neutral (for simplicity), and $r$ is a competitive rate of interest at which the lenders break even, then the interest rate for high-equity/low-leverage borrowers $r^{G}$ will be such that the expected payout to the lenders from project $G$ is exactly equal to the amount loaned to finance $G$. Thus, $r^{G}$ is defined by: ${ }^{323}$

$p^{G}\left(1+r^{G}\right)(I-A)+\left(1-p^{G}\right) F^{G}=I-A$

$r^{G}=\frac{\left(1-p^{G}\right)}{p^{G}} \times\left(1-\frac{F^{G}}{(I-A)}\right)$

The breakeven rate $r_{B}$ for low-equity/high-leverage borrowers is likewise defined by:

$p^{B}\left(1+r^{B}\right)(I-A)=I-A$

$r^{B}=\frac{\left(1-p^{B}\right)}{p}$

It follows from equations (2) and (3) that $r^{B}>r^{G}$. Thus, the interest rate charged by lenders will be higher for companies investing with fewer assets/lower equity.

The implications of this general model for private equity are straightforward. Private equity-owned companies tend to be highly leveraged, so in an end game with lenders, such a company would succumb to moral hazard and invest in worse projects. Knowing this ex ante, lenders will charge it a higher interest rate.

\section{Section 2. Repeated Game Between Borrower and Lender}

In this Section, the lenders are repeatedly lending to a portfolio company of a given private equity firm. The company has a small equity stake $A$, so according to the result derived in Section 1 it should be facing the higher rate of interest $r^{B}$. But the private equity

${ }^{323}$ Per the assumption made above that $F^{G}<(1+r)(I-A)$. If the project fails, the company can only repay the return on the project in the event of failure, $F^{G}$, and not the full amount actually owed, $\left(1+r^{G}\right)(I-A)$. 
firm implicitly commits to invest in the good project through its reputation and thus obtains the lower interest rate $r^{G}$ in the first round of the game. The lenders can always observe after the fact whether the private equity firm has chosen the good or the bad project, given that the outcomes are different under the two, but it cannot control the firm's choice. ${ }^{324}$ The lenders will lend to the portfolio company at interest rate $r^{G}$ because of the private equity firm's good reputation; but if it breaks its reputation in any period by investing in the bad project, it will face interest rate $r^{B}$ in all periods thereafter.

The private equity firm's decision tree is the following:

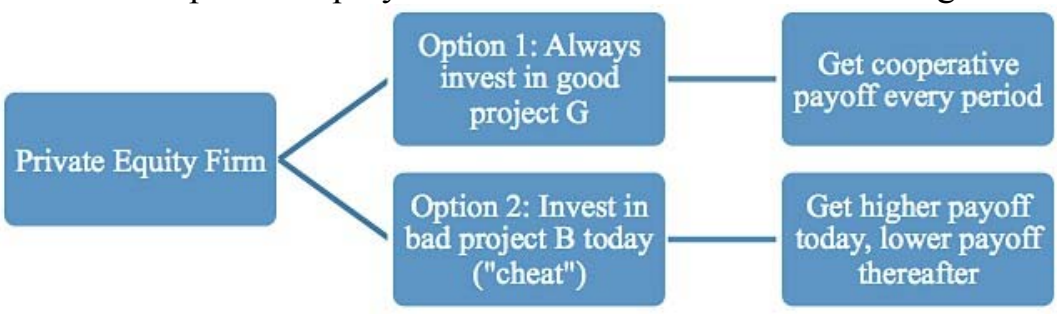

We can now demonstrate that for plausible discount rates, the private equity firm has an incentive to invest always in the good project. It is sufficient to check whether the private equity firm gets a greater return from:

(1) maintaining its reputation forever, thus earning the "cooperative" payoff $p^{G}\left(R^{G}-\left(1+r^{G}\right)(I-A)\right)$ each period; or

(2) breaking its reputation today ("cheating"), thus earning a higher payoff $p^{B}\left(R^{B}-\left(1+r^{G}\right)(I-A)\right)$ for one period, but a lower payoff $p^{B}\left(R^{B}-\left(1+r^{B}\right)(I-A)\right)$ in all periods thereafter.

The higher payoff from cheating is due to the greater attractiveness of the bad project and the low interest rate $r^{G}$ with which the private equity firm starts off.

${ }^{324}$ A more complex model would allow for the possibility of unobservable actions. In that case lenders could not observe directly whether the private equity firm had chosen a good or bad investment opportunity, but when the portfolio company has a bad outcome and cannot repay its loan, the lender looks at the history of past performance and infers the likelihood that the private equity firm chose a bad project. In short, the private equity firm's loan terms would in that case depend on the past history of successes and failures. And again, under plausible conditions, this would motivate private equity firms to invest in good projects. 
The payoffs in future periods must be discounted for time and the likelihood of a continuing lending relationship. Define $\delta=\frac{p}{(1+\mu)}$, where $\mu$ is the time-value of money, $p$ is the probability in any given period that the game will be played again in the next period, and both $\mu$ and $p$ are between 0 and 1 .

As depicted in the decision tree above, the private equity firm has two options:

Option 1: The private equity firm always invests in the good project $G$ in every period, such that its total expected profit will be:

$p^{G}\left(R^{G}-\left(1+r^{G}\right)(I-A)\right)+p^{G}\left(R^{G}-\left(1+r^{G}\right)(I-A)\right) \delta$

$+p^{G}\left(R^{G}-\left(1+r^{G}\right)(I-A)\right) \delta^{2}+\cdots$

$=p^{G}\left(R^{G}-\left(1+r^{G}\right)(I-A)\right)\left[1+\delta+\delta^{2}+\cdots\right]$

$=\frac{p^{G}}{(1-\delta)}\left(R^{G}-\left(1+r^{G}\right)(I-A)\right)$

Option 2: The private equity firm invests in the bad project today (and is therefore punished with the higher interest rate in all subsequent periods), such that its expected profit is:

$p^{B}\left(R^{B}-\left(1+r^{G}\right)(I-A)\right)+p^{B}\left(R^{B}-\left(1+r^{B}\right)(I-A)\right) \delta$

$+p^{B}\left(R^{B}-\left(1+r^{B}\right)(I-A)\right) \delta^{2}+\cdots$

$=p^{B}\left(R^{B}-\left(1+r^{G}\right)(I-A)\right)$

$+\frac{\delta}{(1-\delta)} p^{B}\left(R^{B}-\left(1+r^{B}\right)(I-A)\right)$

Option 2 illustrates that there is a short-term gain from cheating, but a long-term pain: the firm earns less in the periods after it breaks its reputation. ${ }^{325}$

${ }^{325}$ This can be shown by demonstrating that $p^{G}\left(R^{G}-\left(1+r^{G}\right)(I-A)\right)$, the payoff in a period of good reputation, is greater than $p^{B}\left(R^{B}-\right.$ $1+r B I-A$, the payoff in a period of bad reputation. With some calculation, and substituting in the equilibrium values of the interest rates from equations (2) and (3), the proposition is true by definition of the good and bad projects. 
The private equity firm will maintain its good reputation in all periods if its profit from always investing in $G$ (Option 1) exceeds its profit from cheating by investing in $B$ in the first period (Option 2), that is if:

$$
\begin{aligned}
& \frac{p^{G}}{(1-\delta)}\left(R^{G}-\left(1+r^{G}\right)(I-A)\right) \\
& \geq p^{B}\left(R^{B}-\left(1+r^{G}\right)(I-A)\right) \\
& +\frac{\delta}{(1-\delta)} p^{B}\left(R^{B}-\left(1+r^{B}\right)(I-A)\right)
\end{aligned}
$$

which, after some calculation and substituting in the equilibrium values of the interest rates from equations (2) and (3), is equivalent to:

$$
\delta \geq 1-\frac{p^{G} R^{G}-\left(1-p^{G}\right) F^{G}-p^{B} R^{B}}{(I-A)\left(\frac{p^{G}-p^{B}}{p^{G}}\right)+\frac{p^{B}\left(1-p^{G}\right)}{p^{G}} F^{G}}
$$

The numerator of the fraction in the final inequality is positive because the returns to the good project $G$ are better by assumption. And the denominator is positive because $0<p^{B}<$ $p^{G}<1$. Thus, there are always values of $\delta$ close to 1 for which private equity firms will choose to cooperate with lenders. By definition of $\delta$, a value of $\delta$ that is close to 1 requires: (a) a high probability $p$ that the game will be repeated in subsequent periods-a reasonable assumption for private equity firms - and (b) a low time value of money $r$, such that patience will actually be rewarded. ${ }^{326}$

Thus, the fact that private equity firms are in a repeated game with lenders entails that they will cooperate with lenders by mitigating agency costs. In turn, their portfolio companies will be rewarded with better loan terms than comparably leveraged companies can achieve.

\footnotetext{
${ }^{326}$ Conversely, if the time value of money is too high, or the probability that the game will be repeated is too low, the benefit from cheating in the first period will outweigh the long-term pain from being punished by creditors in future periods, and the private equity firm will invest in bad projects.
} 